\title{
O Ministério Público como "Quarto Poder": relevância do reconhecimento para o sistema constitucional
}

\author{
Igor Spock Silveira Santos
}

Mestre e Bacharel em Direito pela Universidade Federal da Bahia (UFBA). Advogado. Email:igor_sss@hotmail.com

\section{Resumo}

O presente artigo aborda a possibilidade de reconhecimento do Ministério Público brasileiro como um "Quarto Poder" na ordem constitucional. Para tanto, investiga-se o surgimento da teoria da repartição das funções estatais, postulando elementos essenciais para a existência de um "Poder". Em seguida, analisa-se a Constituição Federal brasileira e o novo arranjo que foi conferido ao Ministério Público, fazendo-se uma análise histórica do poder de acusar. Entende-se possível o reconhecimento pretendido e argumenta-se acerca da relevância (mais pragmática do que lógica) desta constatação, notadamente quanto à análise de sua relação com os demais Poderes, compondo o sistema de freios e contrapesos, e a necessidade de que a instituição observe o arranjo constitucional vigente, para que não utilize de sua proeminência constitucional para hipertrofiar seu próprio poder.

Palavras-chave

Ministério Público; Separação dos Poderes; Freios e contrapesos; Hipertrofia; Quarto Poder

\section{The Brazilian Prosecutor's Office as a "Fourth Branch": a relevant constitutional recognition}

Abstract

This article discusses the possibility to recognize the Brazilian "Ministério Público" (Prosecutor's Office) as a "Fourth Branch" in the constitutional order. Therefore, it is investigated the appearance of the theory of division of state functions, thus postulating essential elements to the existence of a "Branch". Then it is analyzed the Brazilian Federal Constitution and the new arrangement that was given to the Prosecutor's Office, being made a historical analysis of the power to prosecute. It is taken as a possible recognition 
the one about the relevance (more pragmatic than logic) of this finding, especially to the analysis of its relation with the other branches, participating in the system of checks and balances, besides the need for the institution to observe the current constitutional arrangement, not to use his constitutional prominence to encroach the others.

Keywords

Brazilian Prosecutor's Office; Separation of powers; Checks and balances; Hypertrophy; Fourth Branch.

\section{Sumário}

1. Introdução; 2. A teoria da separação do poder estatal e o sistema de freios e contrapesos; 3. O que constitui um "Poder"; 3.1. O elemento subjetivo; 3.2. O elemento objetivo; 4. O Ministério Público como "Quarto Poder" no Brasil; 5. Relevância prática de reconhecer o Ministério Público como "Quarto Poder"; 5.1. O Ministério Público integra o sistema de freios e contrapesos; 5.1.1. Arquivamento nos procedimentos criminais; 5.1.2. Discordância do órgão julgador quando o Ministério Público postula a absolvição, "mutatio libelli" e "emendatio libelli"; 5.2. A necessidade de não usurpação de funções pelo Ministério Público e a investigação criminal; 6. Conclusões.

\section{Introdução}

Nos Estados contemporâneos o arranjo constitucional das funções estatais costuma ser altamente creditado às ideias de Montesquieu. Se é verdade que o autor teve uma participação decisiva no estabelecimento dos desenhos institucionais contemporâneos, também o é que esta atribuição possui diversas circunstâncias não usualmente relatadas. Uma delas é que o pensador francês, tendo descrito seu ideal de sistema constitucional supostamente com base na Constituição inglesa, o fez em verdade pautado nos relatos de Bolingbroke, um autor que, por motivos políticos, não descreveu fielmente o arranjo de Poderes da época.

Supostamente descrevendo a Constituição inglesa, Montesquieu mesclou caracteres de sua experiência francesa em relação ao Judiciário, e sua teoria, alegadamente adotada na Constituição estadunidense, foi substancialmente alterada pela prática constitucional daquele país, o que acabou influenciando diversos outros, inclusive - Brasil. Com a expansão das atividades estatais, houve uma ainda maior alteração estrutural. Contudo, manteve-se o rótulo da teoria, como se o que hoje pode ser observado fosse quase a mesma postulação de séculos atrás.

Com isso, há a petrificação de alguns elementos que são apenas circunstanciais, sem se atentar exatamente para o fato de que o verdadeiro mérito daquela concepção de poder é a repartição das funções estatais, com o desenvolvimento adicional de possibilitar as limitações recíprocas aos atores governamentais. Mesclando-se o principal com o acessório, cristalizou-se a ideia de que o Estado necessariamente desenvolve três 
atividades principais, e que, portanto, deveria contar com três ramos principais, cada qual precipuamente incumbido de uma daquelas.

A superação desta concepção parece não só ser possível como desejável - ainda que por fatores mais pragmáticos do que lógicos. Emergindo-se novos atores governamentais, cujas participações para o quadro político sejam notáveis, faz-se necessário que haja o devido reconhecimento de que eles também integram o sistema de balanceamento de poderes, e devem observar suas atribuições constitucionais, sem usurpar funções alheias.

Esta mudança na visão constitucional seguramente tem grande aplicação em relação ao Ministério Público brasileiro, o qual emergiu na Constituição Federal de 1988 como um ator político fundamental, sem que, contudo, se tenha dado a devida observação para as consequências práticas que são advindas deste fato. Este trabalho pretende pontuar algumas delas.

\section{A teoria da separação do poder estatal e o sistema de freios e contrapesos}

A teoria da repartição do poder estatal como eixo fundamental da maioria dos Estados contemporâneos encontra-se calcada nos estudos de Montesquieu sobre o modo inglês de governar no século XVIII ${ }^{1}$. É verdade que o autor francês não foi o primeiro a teorizar neste sentido ${ }^{2}$. Ainda na Idade Antiga, Aristóteles já fazia referência à existência de "três partes" do governo: uma estaria encarregada da "deliberação sobre negócios públicos" decidindo soberanamente acerca "da guerra, da paz, da aliança, da ruptura dos tratados", da pronúncia de sentença de morte, exílio ou confisco, da promulgação de leis, além de examinar as contas do $E_{s t a d o}{ }^{3}$; ; outra parte seria responsável por administrar a justiça, julgando os crimes e os litígios civis"; à última caberia exercer as "magistraturas" 5 - apesar

${ }^{1}$ MONTESQUIEU. Do espírito das leis. Gabriela de Andrada Dias Barbosa (trad.). Rio de Janeiro: Nova Fronteira, 2012, v. 1.

${ }^{2}$ Além de Aristóteles, referido neste texto, Paulo Bonavides aponta que "Marsílio de Pádua no Defensor Pacis já percebera a natureza das distintas funções estatais e por fim a Escola de Direito Natural e das Gentes, com Grotius, Wolf e Puffendorf, ao falar partes pontetiales sumii imperii, se aproximara bastante da distinção estabelecida por Montesquieu" (Ciência Política. 18. ed. São Paulo: Malheiros, 2011, p. 146). Há quem aponte que uma doutrina embrionária de separação de poderes pode ser encontrada nos livros bíblicos Êxodo e Juízes (BARENBOIM, Peter. Biblical roots of separation of powers. Moscou: Letny Sad, 2005, p. 23-24).

${ }^{3}$ ARISTÓTELES. A política. Nestor Silveira Chaves (trad.). Rio de Janeiro: Nova Fronteira, 2011, p. 232.

${ }^{4}$ Afirma Aristóteles que, em relação à natureza das causas, há oito espécies de tribunais: "o tribunal que julga agentes devedores; o que decide sobre os delitos públicos; aquele que avoca a 
do termo ser atualmente utilizado para a carreira de juízes, a referência à época seria a funções atualmente desenvolvidas, em boa parte, pelo Poder Executivo ${ }^{6}$.

Percebe-se, neste cenário, um esboço do que atualmente seria o Legislativo, o Judiciário e o Executivo. Na Idade Moderna, Montesquieu costuma ser creditado como tendo sido o primeiro a defender a separação do poder estatal em três partes ${ }^{7}$. Foi com ele que o conceito de separação de poderes tornou-se uma das principais doutrinas do constitucionalismo ${ }^{8}$. Como pilar fundamental deste entendimento estava a ideia de que a observação da história permitiria concluir que "todo homem que tem em mãos o poder é sempre levado a abusar do mesmo; e assim irá seguindo até que encontre algum limite" ${ }^{9}$.

O autor francês sustentou existir em cada Estado "três espécies de poder", quais sejam, "o poder legislativo, o poder executivo das coisas que dependem do direito das gentes, e o poder executivo daquelas que dependem do direito civil" ${ }^{10}$. O primeiro é referente a criar, alterar ou revogar leis; o segundo, relativo à paz e à guerra, à segurança e ao envio ou recebimento de embaixadores; o terceiro, responsável por punir os crimes e julgar os litígios particulares ${ }^{11}$. Se os três poderes estiverem reunidos em uma só pessoa ou um só grupo, não teria como subsistir a liberdade ${ }^{12}$.

Robert Shackleton realiza um estudo detido onde aponta que a doutrina de Montesquieu acerca da separação dos poderes, em verdade, teria sido pautada nas ideias do inglês Bolingbroke, que Ihe foi contemporâneo; contudo, o autor francês teria refinado

si todas as causas em que a constituição é interessada; aquele que decide entre os simples particulares e os magistrados em casos de contestação de penas pronunciadas; aquele que se ocupa dos processos relativos a atribuições particulares, que tenham certa importância; além disso, o tribunal para os estrangeiros e o que toma conhecimento das acusações de homicídio", acrescentando, ainda, "um oitavo que julga as pequenas transações entre particulares, quando o seu valor não passa de cinco dracmas, ou um pouco mais" (ibidem, p. 241-242).

5 Ibidem, p. 232.

${ }^{6}$ Brian Duignan afirma que as atividades referentes à "magistratura" abarcariam "decisões de líderes e outros funcionários públicos"; haveria, assim, a possibilidade de traçar um paralelo com o atual Executivo, embora o autor sustente que a classificação tripartite do autor grego não corresponde exatamente ao que hoje seria o Executivo, o Legislativo e o Judiciário (The executive branch of the federal government: purpose, process, and people. Nova Iorque: Britannica Educational, 2010, p. 21. Traduziu-se). Constata-se que Aristóteles faz referência a algumas funções que compõem a magistratura: general do exército, inspetor de mulheres (ginecomo) ou de crianças (padônomo), funções referentes à Economia (op. cit., p. 236), inspetor de mercado e encarregado do policiamento (ibidem, p. 238). 0 fator decisivo para Aristóteles é que, além de poder deliberar e julgar certos assuntos, o magistrado possa ordenar, caracterizando sua autoridade (ibidem, p. 236).

${ }^{7}$ Conforme afirmado em: DUIGNAN, op. cit., p. 21.

8 Ibidem, p. 21.

${ }_{9}^{9}$ MONTESQUIEU, op. cit., p. 189.

10 Ibidem, p. 190-191.

11 Ibidem, p. 191.

12 Ibidem, p. 191. O autor ressalva que, em reinos da Europa onde o príncipe tem a função de legislar e executar, mas deixa o poder de julgar nas mãos de seus súditos, há um "governo moderado". 
e sistematizado a teoria, que se tornou sua mais distinta e influente contribuição para a doutrina constitucional ${ }^{13}$.

Bolingbroke descreve o poder político inglês da época, no qual ao rei é confiado o Poder Executivo e prerrogativas anexas, enquanto cada uma das duas casas do parlamento possui também seus "direitos e privilégios" exclusivos: à Câmara dos Lordes incumbe a Judicatura Suprema, ao passo que à Câmara dos Comuns cabe julgar os gastos da nação, além de algumas funções que são comuns a ambas as casas, a exemplo da aprovação de leis ${ }^{14}$.

Shackleton afirma ainda que a doutrina de Bolingbroke de separação dos poderes constituiu verdadeira inovação, pois à época (séculos XVII e XVIII) era vigente na Inglaterra a ideia política do Estado misto - ou governo misto - (mixed State/ mixed government), onde o rei, os nobres e o povo eram conjuntamente responsáveis pelo poder de legislar ${ }^{15}$. A constatação quanto à novidade teórica é feita ao examinar que o periódico London Journal, contemporâneo a Bolingborke e ligado ao governo, rebateu a sua doutrina, afirmando que sua tese seria algo fruto da imaginação, que não era aquele o arranjo de poderes na Inglaterra ${ }^{16}$.

Isaac Kramnick, contrapondo Shackleton, defende que as teses afirmadas por Bolingbroke - inclusive a teoria dos freios e contrapesos (checks and balances), que será abordada em seguida - já "estavam colocadas firmemente na sabedoria inglesa convencional e em sua experiência constitucional" ${ }^{17}$. Com efeito, antes de Montesquieu e Bolingbroke, Locke já acenara neste sentido, de que não seria adequado conferir às mesmas pessoas o poder de legislar junto com o de executar as leis, "pois elas poderiam

13 SHACKLETON, op. cit., p. 36-37. Anteriormente à sua conclusão, o autor demonstra que Montesquieu, durante sua estadia de quase dois anos na Inglaterra, era um leitor regular do periódico de Craftsman, da autoria de Bolingbroke, tendo em vista que é possível encontrar citações do periódico no manuscrito da obra Spicilège do autor francês (ibidem, p. 30). Segundo Isaac Kramnick, a doutrina do autor inglês cativou mais Montesquieu do que outras por ambos serem porta-vozes da reação aristocrática ao absolutismo, partilhando das mesmas perspectivas sociais (Bolingbroke and his circle: the politics of nostalgia in the Age of Walpole. Ithaca: Cornell University Press, 1992, p. 150).

14 BOLINGBROKE. Craftsman. Londres: R. Francklin, 1731, v. 7, p. 85. Disponível em: <https://archive.org/stream/craftsman07danv\#page/n7/mode/2up>. Acesso em 24 abr. 2016. 15 SHACKLETON, op. cit., p. 27-28.

16 Ibidem. "Fica claro, então, que Osborne considera que o Craftsman defende algo diferente da ideia tradicional do Estado misto; ele acusa Bolingbroke de conceder ao Rei apenas o poder executivo e atribuir para a Câmara dos Comuns o poder legislativo inteiro. O London Journal acredita que o poder legislativo (ou supremo) está investido no Rei, Lordes e Comuns, que são todos interdependentes. Bolingbroke é decidido em acreditar que o poder executivo, investido no Rei, deve ser separado do poder legislativo, o qual se encontra investido na Câmara dos Comuns: uma separação de poderes que era repugnante para o partido ministerial e derrogatório da dignidade do monarca" (ibidem, p. 35). Traduziu-se.

17 KRAMNICK, op. cit., p. 148-149. Traduziu-se. Assim, o autor questiona a atribuição da novidade da tese dos freios e contrapesos aos escritos de Bolingbroke. 
se isentar da obediência às leis que fizeram, e adequar a lei à sua vontade, tanto no momento de fazê-la quanto no ato de sua execução, e ela teria interesses distintos daqueles do resto da comunidade, contrários à finalidade da sociedade e do governo"18.

O que é importante destacar é que, mesmo para os que sustentam que Bolingbroke não trouxe qualquer inovação teórica, ou ainda para aqueles que entendem que o autor descreveu erroneamente o sistema de "checks and balances" existente na constituição inglesa, suas ideias decisivamente influenciaram Montesquieu, vindo a doutrina de ambos a afetar a elaboração da Constituição dos Estados Unidos ${ }^{19}$, a qual inspirou outras tantas constituições pelo mundo, inclusive as brasileiras ${ }^{20}$.

Esta constatação pode ser feita à análise da obra Federalist, escrito por Alexander Hamilton, James Madison e John Jay, durante os debates de ratificação da Constituição estadunidense. Os escritos tornaram-se "uma importante fonte do direito constitucional", de forma que a "Suprema Corte confia profundamente nestes ensaios" 21. Na obra, podese encontrar a afirmação de que, acerca da separação e distinção dos "três grandes departamentos de poder", "o oráculo que sempre é consultado e citado nesta matéria é o celebrado Montesquieu"22.

Enquanto Montesquieu recebeu dos colonos estadunidenses o crédito pela ideia de separação de poderes, Bolingbroke teve a menção pela doutrina dos freios e contrapesos $^{23}$. Esta doutrina estabelece uma distribuição de atribuições entre os atores

${ }^{18}$ LOCKE, John. Segundo tratado do governo civil: ensaio sobre a origem, os limites e os fins verdadeiros do governo civil. 3. ed. Magda Lopes; Marisa Lobo da Costa (trad.). Petrópolis: Vozes, 2001, p. 170.

${ }^{19}$ BROOKHISER, Richard. Founding father: rediscovering George Washington. Nova Iorque: Free Press Paperbacks, 1997, p. 213. Também neste sentido, tem-se: "Montesquieu naqueles tempos [de elaboração da Constituição] era a grande autoridade. Sua doutrina de que a separação dos poderes executivo, legislativo e judiciário um do outro era essencial para a liberdade foi tida como incontroversa e fundamental" (SMITH, Goldwin. Special introduction. In: HAMILTON, Alexander; JAY, John; MADISON, James. The Federalist. Nova Iorque: The Colonial Press, 1901, p. vi). Traduziu-se.

20 OMMATI, Fides. Dos freios e contrapesos entre os poderes do estado. Revista de Informação Legislativa, Brasília, n. 55, 1977, p. 60-61.

21 FARBER, Daniel A.; SHERRY, Suzanna. Judgment calls: principle and politics in constitutional law. Nova Iorque: Oxford University Press, 2009, p. 76. Traduziu-se. Os autores chegam a sustentar que tais estudos, diante da relevância, devem ser considerados "precedentes não judiciais" (ibidem, p. 78).

22 HAMILTON; JAY; MADISON, op. cit., p. 265. Traduziu-se. Na obra encontra-se ainda uma possível ressalva: "Se ele não for o autor deste preceito inestimável da ciência política, ele ao menos tem o mérito de mostrá-lo e recomendá-lo de forma mais efetiva para a atenção da humanidade" (ibidem, p. 265). Traduziu-se.

23 GUMMERE, Richard M. The classical ancestry of the United States Constitution. American Quarterly, v. 14, n. 1, 1962, p. 7. A influência de Montesquieu, segundo M. J. C. Vile, "não pode ser imputada à sua originalidade neste sentido, mas sim ao modo e à precisão da época [timing] do desenvolvimento da doutrina em suas mãos" (Constitutionalism and the separation of powers. 2. ed. Indianapolis: Liberty Fund, 1998, p. 83). Talvez o motivo pelo qual Montesquieu não foi também apontado como a principal referência na ideia de freios e contrapesos tenha sido o de 
governamentais, criando um mecanismo de limitações recíprocas ${ }^{24}$. Assim, as partes que compõem o governo possuem o poder de "controle e limitação um do outro", uma forma de dependência a qual é resultante da própria divisão dos poderes, como forma de preservação do governo ${ }^{25}$. Esta dependência refere-se à ideia de que os procedimentos de cada uma das partes que possam afetar o todo devem ser passíveis de exame e controle pelas outras partes ${ }^{26}$. Contudo, garante-se a independência interna de cada parte, o que significa que, ao dirigir seus próprios procedimentos, cada uma delas pode fazê-lo sem qualquer influência, direta ou indireta, das demais ${ }^{27}$.

Para Bolingbroke, se qualquer destas três partes que compõem o governo tentar usurpar mais poder do que a Constituição e a lei lhe fornecem, as outras duas partes podem unir suas forças e reconduzi-la aos seus limites corretos; se duas tentarem a usurpação, a terceira pode ao menos retardar o ato, provendo tempo e chance para impedi-la ${ }^{28}$. Ao fazer esta colocação, o autor conclui que este é o "balance" (equilíbrio/contrapeso) que se usado corretamente pode salvar a Constituição, arrematando: "em uma Constituição como a nossa [a inglesa], a segurança do todo depende do equilíbrio das partes" 29 . Nas palavras de Montesquieu, "para que não se possa abusar do poder, é preciso que, pela disposição das coisas, o poder refreie o poder" 30 .

Assim, junto à ideia de independência dos poderes, há também uma interdependência recíproca. Conforme se depreende do Federalist, a separação de poderes não poderia existir se os "ramos" do governo não estivessem tão bem conectados a ponto de cada um exercer um controle constitucional sobre os outros ${ }^{31}$. Isto porque a mera declaração dos limites escrita na constituição não é suficiente para manter os poderes nos seus limites legais ${ }^{32}$. Minimizou-se a necessidade da rígida separação

que este entendia que o poder executivo teria seus limites pela sua natureza, pelo que não seria necessário que o legislativo o refreasse; em sentido contrário, o executivo deveria ter o direito de controlar em alguma medida o corpo legislativo, para que este não atribuísse a si todo o poder imaginável, tornando-se despótico, utilizando o instituto do veto (op. cit., p. 198-200). Esta visão reduzida do sistema de limitações pode o ter afastado do posto de principal referência.

${ }^{24}$ OMMATI, op. cit., p. 60.

25 BOLINGBROKE, op. cit., p. 86-87.

26 Ibidem, p. 87.

27 Ibidem, p. 87.

28 Ibidem, p. 86.

29 Ibidem, p. 86.

30 MONTESQUIEU, op. cit., p. 190. Uma ideia incipiente neste sentido pode ser encontrada em Locke, o qual, embora defendendo a existência de um "poder supremo", que seria o legislativo, afirma que os poderes ministeriais e demais poderes subordinados existentes em uma sociedade devem sempre prestar contas a algum outro poder existente (op. cit., p. 175).

${ }^{31}$ HAMILTON; JAY; MADISON, op. cit., p. 271.

32 Ibidem, p. 280. 
funcional, focando-se mais na ideia do sistema de freios e contrapesos ${ }^{33}$. Contudo, cada um dos "departamentos" do poder não pode exercer uma influência predominante sobre a administração interna dos respectivos poderes ${ }^{34}$.

$\mathrm{Na}$ Constituição dos Estados Unidos foram estabelecidos diversos dispositivos que visavam ao controle entre os atores governamentais - havendo não só a institucionalização da diferenciação funcional dos poderes, como também do sistema de freios e contrapesos ${ }^{35}$-, muitos dos quais embasados no sistema de limitações existentes na constituição inglesa ${ }^{36}$. A maior parte deles são também observados na tradição constitucional brasileira ${ }^{37}$, e estão presentes na Constituição Federal de 1988, a exemplo do poder do executivo de vetar leis, do legislativo de derrubar o veto e proceder ao impeachment, e do judiciário de realizar o controle de constitucionalidade dos atos normativos dos outros poderes ${ }^{38}$.

Feita esta análise, parece acertada a observação de que não há propriamente uma "separação" de poderes, mas sim uma distribuição de poderes, vindo cada órgão a apresentar apenas uma preponderância em determinadas funções ${ }^{39}$. Mesmo porque,

33 BELLAMY, Richard. The political form of the constitution: the separation of powers, rights and representative democracy. Political Studies, v. 44, n. 3, 1996, p. 447-448.

34 HAMILTON; JAY; MADISON, op. cit., p. 271.

35 KEMP, Christopher. Madison, Montesquieu and the separation of powers. In: COULSON, Andrew (ed.). Scrutiny: theory and practice in local governance. Birmingham: University of Birmingham, 2010, p. 50.

36 Sobre a Constituição inglesa, observa-se que "O magistrado em quem todo o poder executivo reside não pode ele mesmo fazer uma lei, embora ele possa colocar um veto em toda lei; nem administrar a justiça pessoalmente, embora ele tenha a indicação daqueles que a administra. Os juízes não podem exercer qualquer prerrogativa executiva, embora eles sejam frutos do executivo; nem qualquer função legislativa, embora eles podem ser aconselhados por conselhos legislativos. A legislatura inteira não pode realizar qualquer ato judiciário; embora pelo ato conjunto de suas duas casas os juízes possam ser removidos dos seus ofícios; e embora uma de suas casas seja investida com poder judicial como último recurso. A legislatura toda, novamente, não pode exercer qualquer prerrogativa executiva, embora uma de suas casas constitua a suprema magistratura do executivo, e a outra, no impedimento de um terço, pode julgar e condenar todos os ofícios subordinados no departamento executivo" (HAMILTON; JAY; MADISON, op. cit., p. 266). Traduziu-se.

37 "São freios do Legislativo sobre o Executivo o impeachment, a rejeição do veto, a aprovação de nomeação para determinados cargos, a aprovação de tratados internacionais a fiscalização dos atos do Executivo através das Comissões Parlamentares de Inquérito e do controle orçamentário" (OMMATI, op. cit., p. 62). Para outros limites apontados entre os poderes, em relação à constituição brasileira vigente à época: (ibidem, p. 61-80).

38 CUNHA JR., Dirley. Curso de Direito Constitucional. 7. ed. Salvador: Juspodivm, 2013, p. 531532.

39 KELSEN, Hans. Teoria geral do direito e do estado. Luís Carlos Borges (trad.). 3. ed. São Paulo: Martins Fontes, 2000, p. 390. A mesma conclusão é obtida em: KIMMINICH, Otto. A jurisdição constitucional e o princípio da divisão dos poderes. Anke Schlimm e Gilmar Ferreira Mendes (trad.). Revista de Informação Legislativa, Brasília, n. 105, 1990, p. 291. Sobre a possibilidade do legislativo de julgar, Montesquieu defendia três hipóteses para esta ocorrência: o julgamento de nobres, que não poderiam estar sujeitos aos tribunais ordinários; em casos que a lei fosse demasiadamente rigorosa e fosse necessário abrandá-la; e caso algum cidadão cometesse ilícitos nos negócios públicos (op. cit., p. 199). 
ainda que não se considere especificamente os mecanismos do sistema de freios e contrapesos, há situações nas quais "para o integral desempenho de suas próprias funções típicas" é necessário exercer uma função que, numa perspectiva rígida, só caberia a outros atores estatais ${ }^{40}$.

Conquanto atualmente a noção de divisão das funções estatais entre diferentes atores pareça elementar, anteriormente a autores como Montesquieu, Bolingbroke e Locke havia a ideia de que os poderes deveriam estar todos reunidos, como forma de garantir a paz e a estabilidade. Por exemplo, em meados do século XVII, Thomas Hobbes, que precedeu aos autores referidos logo acima, sustentava que todos os poderes pertenciam ao soberano - que poderia ser uma única pessoa ou assembleia - sendo eles indivisíveis, inseparáveis; se qualquer um deles fosse alienado, a guerra seria inevitável ${ }^{41}$. Posteriormente, na Inglaterra do século XVIII, a prática constitucional inglesa era da existência de uma soberania do parlamento ${ }^{42}$, órgão que ganhou destaque após a Revolução Gloriosa de $1688^{43}$.

Esta exposição serviu para demonstrar que o princípio da separação dos poderes, fundamental para o constitucionalismo, deve ser tratado, em verdade, como uma divisão das funções estatais para múltiplos atores, os quais resguardam uma função predominante, mas acabam por exercer outras ${ }^{44}$. É também necessário que cada um destes ramos do governo possua meios de limitar e contrabalancear os outros autores, para que não haja hipertrofia de nenhum deles, fazendo funcionar o chamado sistema de freios e contrapesos, sem o qual a divisão de poderes estaria fadada ao fracasso ${ }^{45}$.

\section{O que constitui um "Poder"}

\footnotetext{
40 CUNHA JR., op. cit., p. 532.

41 HOBBES, Thomas. Leviathan: or the matter, forme \& power of a commonwealth, ecclesiasticall and civil. Cambridge: Cambridge University, 1904, p. 126-127.

42 KEMP, op. cit., p. 51.

43 SARLET, Ingo Wolfgang; MARINONI, Luiz Guilherme; MITIDIERO, Daniel. Curso de Direito Constitucional. 3. ed. rev. atual. ampl. São Paulo: Revista dos Tribunais, 2014, p. 856.

44 "Os teóricos mais extremados da dicotomia 'política x administração' sugerem que o funcionário público da administração simplesmente exerce uma função técnica que é direcionada para a execução de normas estabelecidas para ele pelos ramos políticos do governo. Assim eles pensam em termo de uma 'função administrativa'. Mas, em verdade, estes funcionários públicos, sem qualquer intenção de abusar de seus poderes, inevitavelmente criam, interpretam e aplicam normas" (VILE, op. cit., p. 350). Traduziu-se.

45 Ibidem, p. 2.
} 
A ideia de "Poder", em um sentido político, implica a assunção de uma relação de autoridade, possibilitando a submissão de indivíduos à ordem jurídica ${ }^{46}$. O "Poder" do Estado, ao qual as pessoas estão sujeitas, só pode ser uno, entendido como a validade e eficácia da ordem jurídica nacional ${ }^{47}$. Quando se refere ao Poder Executivo, Legislativo e Judiciário, em verdade, apenas se aborda três funções estatais ${ }^{48}$, as quais se fez comum o uso para designar cada um dos diferentes atores governamentais, de acordo com sua atribuição preponderante.

Conforme assenta Kelsen, a cognição humana tem a tendência de personificar abstrações como o Estado, realizando então uma hipóstase, a atribuição de uma existência substancial ao que era ficção e passou a ser personificado ${ }^{49}$. Assim é que a função predominante de determinado ator governamental passou a denominar este próprio ator, como se lhe fosse algo inerente, essencial, impossível de ser configurado de outra forma: o Poder Executivo, o Poder Legislativo e o Poder Judiciário. O que se faz neste trabalho, neste momento, é exatamente buscar decompor estes dois elementos: um elemento "subjetivo", relativo aos atores governamentais, e outro "objetivo", relativo às funções estatais.

Antes, contudo, tem-se uma ressalva: entende-se que, logicamente, nem mesmo seria necessário falar em "poderes", mas tão somente em instituições governamentais que desenvolvem funções, exclusivas ou não, que se interpenetram e possibilitam o controle mútuo das atividades estatais, impedindo a concentração de poder em detrimento de direitos. Bastaria esta premissa para que fosse desenvolvida a argumentação que se pretende. Contudo, considerando-se a força persuasiva que a teoria dos "Poderes" possui no quadro constitucional contemporâneo, exercendo forte argumento de presença ${ }^{50}$, torna-se mais fácil propor uma menor alteração na teoria do que a sua superação.

\subsection{0 elemento subjetivo}

Antes de adentrar o exame do "elemento subjetivo", deve-se destacar que chega a ser difícil visualizar a separação de ambos, especialmente por conta da tradição constitucional, principalmente calcada em Montesquieu, de que existiriam três funções estatais, e, portanto, deveria haver três órgãos para serem responsáveis por cada uma

46 KELSEN, op. cit., 274.

47 Ibidem, p. 364.

48 Ibidem, op. cit., p. 365.

49 Ibidem, op. cit., p. 275.

50 Sobre o tema: PERELMAN, Chaïm; OLBRECHTS-TYTECA, Lucie. 2. ed. Maria Ermantina de Almeida Prado Galvão (trad.). São Paulo: Martins Fontes, 2005, p. 132. 
delas, que acabaram recebendo o nome respectivo à função que supostamente exerceria exclusivamente. Contudo, insta salientar que a doutrina da separação dos poderes, em sua concepção original, raramente foi aplicada 51 .

Conforme aponta Karl Loewenstein, a doutrina de que os poderes políticos de um estado devem, necessariamente, ser distinguidos e separados de acordo com o objetivo da atividade estatal funciona mais como uma ideologia política do que como um verdadeiro modelo de organização política, conquanto tenha sido útil no período entre a monarquia absoluta e o completo desenvolvimento do estado constitucional ${ }^{52}$. A divisão do governo em três mostra-se mais como um componente "místico", que já foi calcado na ideia de espelhar a Santíssima Trindade, ou mesmo de manter um número ímpar ao invés de par, e não parece justificado atualmente ${ }^{53}$.

O que se pretende apontar neste tópico é que a repartição do poder estatal entre três atores principais não é a única possibilidade constitucionalmente possível.

Anteriormente, neste trabalho, já foi apresentada a visão de Aristóteles acerca das três partes do governo. Também este autor, em algumas circunstâncias, não diferenciava matérias que seriam da "magistratura" ou da "deliberação dos negócios públicos", pelo que, a depender da cidade-estado, seria possível que determinadas matérias fossem decidas apenas pela magistratura ("executivo"), enquanto em outras localidades seria por todo o povo (“legislativo") 54 .

51 BELLAMY, op. cit., p. 439. Uma definição desta "teoria pura" da separação dos poderes é apresentada por Vile: "É essencial para o estabelecimento e manutenção da liberdade política que o governo seja dividido em três ramos ou departamentos, o legislativo, executivo e do judiciário. Para cada um destes três ramos há uma correspondente função de governo identificável, legislativo, executivo ou judicial. Cada ramo do governo deve limitar-se ao exercício da sua própria função e não tem permissão para usurpar as funções dos outros ramos. Além disso, as pessoas que compõem estas três agências de governo devem ser mantidas separadas e distintas, sem que nenhum indivíduo seja autorizado a ser ao mesmo tempo um membro de mais de um ramo. Desta forma, cada um dos ramos será um limite para os outros e nenhum grupo de pessoas será capaz de controlar a máquina do Estado" (op. cit., p. 14) Traduziu-se.

52 LOEWENSTEIN, Karl. The balance between legislative and executive power: a study in comparative constitutional law. University of Chicago Law Review, v. 5, n. 4, 1938, p. 567.

53 VILE, op. cit., p. 16.

${ }^{54}$ Assim, afirma Aristóteles que, em alguns governos "as deliberações são feitas nas reuniões de magistrados (...) só existe assembleia geral de todo povo quando se trata de promulgar leis, regular os negócios do governo, ou proclamar os decretos dos magistrados" (op. cit., p. 232233). Outra possibilidade, mais restritiva da participação dos cidadãos, seria que eles apenas deliberassem sobre guerras, alianças e tomadas de contas, além de poder eleger os magistrados, aos quais incumbiriam todas as demais questões (ibidem, p. 233). Haveria ainda a possibilidade de "submeter todas as questões à deliberação do povo em geral, não deixando aos magistrados o poder de resolver sobre o que quer que seja" (ibidem, p. 233). De forma semelhante, em relação aos julgamentos, haveria a possibilidade de que estes fossem realizados por todos os cidadãos, o que se assemelharia à assembleia geral (ibidem, p. 243). 
Na modernidade, mesmo Hobbes parecia já entender que o poder estatal poderia ser partilhado subjetivamente, entre várias pessoas, embora afirmando que cada uma delas teria uma cota de todos os poderes, que deveriam necessariamente permanecer todos juntos ${ }^{55}$. Esta situação, contudo, contraria a ideia aqui apresentada de que o poder estatal não deve ser atribuído a uma única entidade, pelo risco à liberdade. Locke, que escreveu após a superação do ideal absolutista monárquico, defendeu que haveria equilíbrio político suficiente se houvesse dois "Poderes"

Embora a divisão tripartite do poder seja creditada, na modernidade, à obra de Montesquieu, o próprio autor entendia que o "Judiciário" seria um poder "nulo", pelo que "restam portanto dois"57 - havendo até mesmo quem entenda que esta situação do Judiciário subsiste ainda hoje na França ${ }^{58}$. O autor francês apontava que o contrabalanceamento entre o corpo Legislativo do povo e o Executivo deveria ser feito pela parte do Legislativo composta pelos nobres, que por sua vez poderia ser refreada, em determinado tema, pela parte popular do Legislativo ${ }^{59}$.

Entretanto, conforme já referido, a Constituição dos Estados Unidos - pautada em uma divisão de poderes que nem o próprio Montesquieu pareceu ter defendido terminou por consagrar três atores governamentais, e ela influenciou diversos textos constitucionais de todo o mundo. Já foi destacado, contudo, que o "Artigos de Confederação", que precedeu a Constituição em si, trazia a existência de apenas dois ramos do governo, sem indicar o "Executivo"60.

Em verdade, o poder estatal pode ser partilhado em qualquer combinação subjetiva que se entenda possível, desde que seja mantido o sistema de freios e contrapesos entre estes atores. Brian Duignan chega a sustentar que - em razão da desconfiança dos revolucionários originadas a partir das experiências com os governadores coloniais, que construíram a impressão de que o "Executivo" era inimigo da liberdade -, a existência da Presidência foi uma serendipidade: seria "seguro afirmar que

55 Esta interpretação da obra do autor é fornecida em: SHACKLETON, op. cit., p. 26.

56 LOCKE, op. cit., p. 135.

57 MONTESQUIEU, op. cit., p. 196.

58 Segundo René David, enquanto no direito inglês seria possível falar na existência de um "poder judiciário", na França haveria apenas "uma função jurisdicional, autoridades judiciárias, mas não, verdadeiramente, um poder judiciário", razão pela qual a própria Constituição francesa faz uso da expressão "autoridade judiciária", como forma de refletir terminologicamente o que já havia na realidade ( $O$ direito inglês. 2. ed. Eduardo Brandão (trad.). São Paulo: Martins Fontes, 2006, p. 17-18).

59 MONTESQUIEU, op. cit., p. 196. Mais recentemente, houve quem apontasse que a situação seria diferente, não sendo possível falar propriamente em separação de poderes no parlamentarismo, por haver uma espécie de fusão entre os poderes, pautada na dominação do executivo sobre o legislativo (LOEWENSTEIN, op. cit., p. 594).

60 DUIGNAN, op. cit., p. 30. 
se [George] Washington não estivesse disponível, a função poderia nunca ter sido criada" 61 .

Não apenas é possível ter menos que três atores estatais, como também é viável que existam mais que este número. Na Venezuela, existe um ramo governamental com status de "Poder" - assim como o Legislativo, Executivo e Judiciário - dedicado às atividades eleitorais, chamado "Poder Eleitoral"62. Além deste, há ainda o "Poder Cidadão", com objetivo de aumentar a capacidade de fiscalização do Estado63, sendo composto pela Defensoria do Povo, Ministério Público e Controladoria Geral da República, com presidência rotativa entre eles (art. 273). Ou seja, há cinco "Poderes". Há quem aponte que o ideal no Brasil seria a existência de sete "Poderes"64, de acordo com diferentes funções estatais.

Com base no que foi examinado acerca das doutrinas da "separação dos poderes" e do sistema de freios e contrapesos, o que parece fundamental para reconhecer o elemento subjetivo de um "Poder" é que ele seja um órgão autônomo, nos âmbitos administrativo e financeiro ${ }^{65}$, sem qualquer tipo de vinculação hierárquica aos demais. Evidentemente, nem toda instituição que reúna os requisitos acima poderia ser descrita como um "Poder". Ao elemento subjetivo deve ser acrescentado o elemento objetivo.

61 Ibidem, p. 30-31. Traduziu-se. 0 autor aponta que esta seria a razão pela qual matérias que tradicionalmente seriam do Executivo foram conferidas ao Congresso, a exemplo do poder de declarar guerra, cunhar moedas e fazer empréstimos (ibidem, p. 30-31).

62 HERNẤNDEZ, Janeth. Organización electoral y credibilidade: caso Venezuela (1989-2005). Cuestiones Políticas, v. 22, n. 37, 2006, p. 104.

63 BOTELHO, João Carlos Amoroso. A democracia na Venezuela da era chavista. Aurora, v. 1, n. 2, 2008, p. 23.

64 “(...) hoje é necessário separar as seguintes funções autônomas do Estado democrático: a função legislativa ordinária (de elaborar as leis infraconstitucionais); a função legislativa constitucional (de emendar e revisar a Constituição); a função jurisdicional; a função de governo; a função administrativa; a função de fiscalização (acima mencionada) [Ministério Público, Tribunal de Contas e Defensoria Pública]; e uma função simbólica (típica do chefe de Estado, função que, pelo seu simbolismo, não deve se confundir com a função de governo, esta de poder político)" (MAGALHÃES, op. cit., p. 97).

65 "A Constituição assegura, logo no artigo $2^{\circ}$, a independência dos três poderes - Legislativo, Executivo e Judiciário. A independência pressupõe autonomia, e esta tem em seu aspecto financeiro o pilar mais importante. Não há independência sem autonomia financeira" (CONTI, José Maurício. Poderes não são independentes sem autonomia financeira. Conjur, 27 ago. 2013. Disponível em: <http://www.conjur.com.br/2013-ago-27/contas-vista-poderes-nao-saoindependentes-autonomia-financeira>. Acesso em 03 jul. 2016). Também neste sentido, embora fazendo o destaque apenas para o judiciário: ABREU, João Paulo Pirôpo de. A autonomia financeira do poder judiciário: limites traçados pelo princípio da independência e harmonia dos poderes. Dissertação (mestrado em Direito). Universidade Federal da Bahia, 2012, p. 151. Ainda: "A participação necessária do Poder Judiciário na construção do pertinente diploma orçamentário diretivo, em conjugação com os outros Poderes instituídos, é reflexo do status constitucional da autonomia e da independência que lhe são atribuídas no art. 2 o do Diploma Maior" (STF. Tribunal pleno. ADI 4.426. Rel. Min. Dias Toffoli. Julg. 09.02.2011, DJe 18.05.2011). 


\subsection{0 elemento objetivo}

A doutrina de Montesquieu, conforme já visto, sedimentou na tradição constitucional a ideia de que existem três funções estatais: legislar, julgar e executar. A separação proposta pelo autor é, no entanto, questionável do ponto de vista lógico. Examinando sob este prisma, haveria apenas duas funções estatais: a elaboração de normas abstratas e a execução delas em situações concretas $^{66}$. Esta execução, em um sentido mais amplo, abarca as atividades normalmente designadas como "executar" e "julgar", atribuídas aos chamados poder executivo e poder judiciário, sendo possível considerar que, "neste aspecto, a função de ambos é realmente a mesma" ${ }^{67}$.

Montesquieu tenta diferenciar o Judiciário do Executivo e do Legislativo justificando que estes dois "não atuam sobre nenhum particular". Contudo, demonstrando sua contradição, o autor afirma que o executivo teria o direito de aprisionar cidadãos ${ }^{68}$. Ademais, atualmente há diversas situações em que o "Executivo" exerce a mesma atividade "judicante" que os tribunais, através dos processos administrativos $^{69}$. Evidentemente, a regulação jurídica de uma e outra atividade pode ser diferente $^{70}$, notadamente quanto à aptidão para fazer coisa julgada material ${ }^{71}$. Mas é possível conceber um ordenamento jurídico no qual todas as leis fossem executadas imediatamente pelos agentes estatais, sem haver um procedimento mais desenvolvido, com garantia de defesa, e todos os outros elementos que terminaram por caracterizar a

66 VILE, op. cit., p. 24.

67 KELSEN, op. cit., p. 365. De forma mais completa, o autor sustenta: "As normas jurídicas gerais são executadas tanto pelo poder executivo quanto pelo judiciário; a diferença é, simplesmente, que, num caso, a execução das normas gerais é confiada aos tribunais e, no outro, aos chamados órgãos 'executivos' ou administrativos. Assim, a tricotomia usual é, no fundo, uma dicotomia, a distinção fundamental entre legis latio e legis executio. A segunda função, no sentido mais restrito, está subdividida em função jurídica e função executiva".

68 MONTESQUIEU, op. cit., p. 193. A afirmação do autor é de que o Legislativo não poderia permitir que o Executivo aprisionasse cidadãos que apresentassem caução [fiança], exceto se foram presos "para responder sem demora a uma acusação que a lei considere capital".

69 KELSEN, op. cit., 392.

${ }^{70}$ Alguns aspectos mais relevantes, em relação ao direito brasileiro, são apontados em: DIDIER JR., Fredie. Curso de Direito Processual Civil: introdução ao direito processual civil, parte geral e processo de conhecimento. 17. ed. Salvador: Juspodivm, 2015, v. 1, p. 191-195, notadamente o potencial de realização de coisa julgada material.

71 CANOTILHO, J. J. Gomes. Direito constitucional e teoria da constituição. 7. ed. Coimbra: Almedina, 2003, p. 264-266. Ressalva, contudo, que na França existem tribunais administrativos cujas decisões fazem coisa julgada material (MAGALHÃES, José Luiz Quadros de. A teoria da separação de poderes e a divisão das funções autônomas no Estado contemporâneo: o Tribunal de Contas como integrante de um poder autônomo de fiscalização. Revista do Tribunal de Contas do Estado de Minas Gerais, v. 71, n. 2, 2009, p. 95). 
atuação judicial $^{72}$ - em que pese a indesejabilidade de um estado regulado desta forma, pelos perigos à liberdade e demais direitos.

Montesquieu também tenta diferenciar o Poder Executivo sustentando que ele é "exercido sempre sobre coisas momentâneas" 73. Mas isso não o diferenciaria propriamente do Poder Judiciário, tendo em vista que a sua atuação também muitas vezes ocorre apenas sobre coisas momentâneas - a exemplo da decisão sobre a sanção a algum indivíduo. Além disso, é possível que a constituição de alguns Estados confira ao Legislativo funções "sobre coisas momentâneas" 74 .

A própria visão do autor francês de que o poder executivo seria a mera execução da vontade geral do Estado (Legislativo) ${ }^{75}$ coaduna-se com a célebre colocação de que o juiz seria apenas "a boca que pronuncia as palavras da lei", "seres inanimados", que não poderiam moderar nem a força nem o rigor da $\mathrm{lei}^{76}$, pelo que o julgamento representaria sempre um texto fixo da lei ${ }^{77}$. Robert Shackleton entende que, diante do caráter latente que Montesquieu confere ao Judiciário, a independência dos poderes basicamente abrangeria o Executivo e o Legislativo ${ }^{78}$. Para o autor francês, o Judiciário seria um poder "de algum modo nulo"79. Deve-se salientar, no entanto, que Montesquieu, supostamente descrevendo a Constituição inglesa, caracterizou o Judiciário de acordo com sua experiência francesa, sem entender o funcionamento do sistema de common law, notadamente a construção de precedentes, que seria uma atividade legislativa ${ }^{80}$.

72 “A instituição do júri para determinar questões de fato é uma forma procedimental específica de salvaguardar certos valores na aplicação do direito, tendo em vista que estes julgamentos de fatos poderiam ser determinados por um funcionário em uma função administrativa; porém, as questões sob consideração são tidas como tão importantes para os indivíduos que existe um procedimento especial para determina-las. A ideia de 'lide' [dispute], que é constantemente dita como caracterizadora do exercício de poder judicial, dificilmente é tão importante. Muitas dessas 'lides' que vão às cortes não o são verdadeiramente, mas são arranjadas para parecer com elas, de forma que o procedimento judicial seja aplicado" (VILE, op. cit., p. 360). Traduziuse.

73 MONTESQUIEU, op. cit., p. 198.

${ }^{74}$ Aristóteles apontava que, na Grécia Antiga, a prerrogativa de decidir sobre a guerra era da Assembleia Geral (op. cit., p. 232). Também no sistema estadunidense é competência do Legislativo (DUIGNAN, op. cit., p. 11), ainda que Abraham Lincoln tenha desrespeitado esta regra, convocando a milícia dos estados do Norte, aumentando o tamanho das Forças Armadas e os gastos com esta atividade, sem a aprovação do Congresso (ibidem, p. 13). Aliás, também era prerrogativa do "Legislativo" daquela época atividades que atualmente dificilmente caberiam a este poder, a exemplo dos atos de - nos ordenamentos jurídicos que os prevejam - confisco, pronúncia de sentença de morte, exílio (ibidem, p. 232).

75 MONTESQUIEU, op. cit., p. 193.

76 Ibidem, p. 199.

77 Ibidem, p. 193.

78 SHACKLETON, op. cit., p. 26.

79 MONTESQUIEU, op. cit., p. 196.

80 CLAUS, Laurence. Montesquieu's mistakes and the true meaning of separation. Oxford Journal of Legal Studies, v. 25, n. 3, 2005, p. 431-432. Tem-se "Quando Montesquieu abordou o poder legislativo, ele quis dizer o poder de fazer lei, por qualquer um que a possuísse. Mas resolver 
O ponto a ser demonstrado é que, afora a possibilidade de firmar precedentes que seria atividade legislativa - os tribunais exercem função logicamente semelhante ao que se costuma chamar Poder Executivo. Note-se que, antes de Montesquieu, a "vasta maioria" dos escritores entendiam que a função judicial estaria abarcada pelos deveres inerentes ao Executivo ${ }^{81}$.

Locke, ao fazer referência à "totalidade do poder", menciona apenas "Legislativo e Executivo" $^{82}$. O Poder Executivo é aquele que visa ao cumprimento das leis da sociedade e marca a transferência do "poder de punir" individual - que existe quando não há governo, ou seja, no "estado de natureza" - para o poder de punir a cargo de titulares nomeados entre o grupo ${ }^{83}$. O Poder Legislativo é o responsável por estabelecer as leis que regem o bem comum, sendo este o "Poder Supremo" 84.

Portanto, dentro desta perspectiva, conforme já referido, pode-se afirmar que existem apenas duas funções estatais: elaborar normas e aplicá-las. Contudo, fazer esta divisão genérica não contribui muito para o exame das atividades estatais. É preciso que haja um maior detalhamento entre uma e outra categoria, de forma a otimizar a distribuição destas funções. No século XVII, Thomas Hobbes, embora sustentando a concentração de todos os poderes, apontava cerca de uma dezena de diferentes atividades estatais ${ }^{85}$. Atualmente seriam diversas vezes mais. Como este trabalho não se propõe a esta finalidade específica, será feito um desenvolvimento mais geral, mas propício a desvelar uma conclusão parcial relevante. Para tanto, examinar-se-á diferentes tipos de atividades estatais que podem ser distribuídas entre os atores governamentais.

Locke, embora aborde basicamente o poder legislativo e o executivo, faz também referência à existência do "Poder Federativo", relativo à administração da segurança e do

disputas podem requerer explicação judicial da lei existente. Explicação é elaboração. Elaborar é legislar (lawmaking). Por quê? Porque a doutrina do precedente o faz ser assim. Se o tribunal usa mais palavras para explicar por que uma lei deve ser aplicada para os fatos determinados do que o legislador utilizou na lei, e se o tribunal leva em consideração estas palavras adicionais, então a explanação judicial obteve êxito em suplementar a lei". Traduziu-se.

81 BELLAMY, op. cit., p. 444. Também constatando a visão dual das funções abstratas do governo no século XVII: VILE, op. cit., p. 33. 0 autor explica como esta concepção foi transformada na ideia tripartite através dos escritos de George Lawson no século XVII, descrevendo a história como "complicada" (ibidem, p. 60-63).

82 LOCKE, op. cit., p. 135.

83 Ibidem, p. 157-158.

84 Ibidem, p. 159-160.

85 Para o autor, são algumas destas funções: adotar quaisquer medidas necessárias para garantir a paz e segurança interior e exterior; decidir quais doutrinas devem ser ensinadas e quais devem ser proibidas; elaborar as regras que devem ser seguidas pelos indivíduos na sociedade; julgar todas as controvérsias, seja com base no direito civil ou no direito natural; fazer a guerra e a paz; recolher os tributos necessários para o custeio do Estado; escolher todos os funcionários do Estado; o direito de recompensar ou punir indivíduos (HOBBES, op. cit., p. 123-126). 
interesse público externo à sociedade, já que o poder executivo estaria incumbido apenas da ordem interna ${ }^{86}$. Este Poder Federativo, segundo o autor, não deveria ser entregue a pessoas distintas daquelas que já possuem o Poder Executivo, malgrado fosse um poder distinto, bem como dificilmente se pudesse deixar guiar por leis preexistentes aprovadas pelo Legislativo ${ }^{87}$.

O que é fundamental perceber no raciocínio do autor inglês é que há um âmbito de atuação governamental que é externo, em relação aos outros estados. Esta atividade pode ser tanto "legislativa", de elaboração de normas abstratas, a exemplo de tratados e convenções, quanto de execução delas em situações concretas. Este plano de ação envolve a possibilidade de fazer a guerra e a paz, adotando todas as medidas necessárias para garantir a segurança do estado ${ }^{88}$. Esta função externa pode ser exercida pelo chefe do "poder executivo" 89 ou por órgão parlamentar"90.

As descrições das funções dos atores estatais, contudo, normalmente estão mais focadas nas atividades internas. Uma destas atividades é garantir que os indivíduos obedeçam à lei. Esta função interna pode ocorrer através de um procedimento com caracteres especiais no âmbito de um tribunal ${ }^{91}$, que normalmente são as atividades conferidas ao assim chamado poder judiciário, ou não, sendo normalmente atribuídas ao chamado Executivo ${ }^{92}$.

${ }^{86}$ LOCKE, op. cit., p. 171.

87 Ibidem, p. 172.

${ }^{88}$ HOBBES, op. cit., p. 125.

${ }^{89}$ A Constituição Federal de 1988 prevê que a atribuição para declarar a guerra é do presidente da república (art. 84, XIX). Para tanto, deve haver autorização ou referendo do Congresso (art. 49, II).

90 Durante a Guerra de Independência dos Estados Unidos, os treze Estados existentes à época firmaram o "Artigos de Confederação" (1781), que seria a primeira constituição "nacional", mas que não trazia a existência de um Poder Executivo, indicando caber ao Senado a realização das atividades relativas ao que seria este ramo do governo, a exemplo da condução da política externa (DUIGNAN, op. cit., p. 30).

91 “(...) tem sido argumentado que o Judiciário aplica a lei igualmente aos funcionários públicos administrativos, mas através de um procedimento diferente (...) Se nós examinarmos o trabalho dos tribunais, podemos perceber que, em um sentido geral, eles estão aplicando as normas feitas pelo legislador ou por outros tribunais (...) Portanto podemos dizer que os tribunais aplicam a lei, mas o fazem de um modo especial, através de um procedimento especial" (VILE, op. cit., p. 359-360).

92 Assim, para exemplificar, uma empresa que descumpra normas ambientais poderá ter sua situação analisada tanto pelo poder executivo quanto pelo judiciário (THOMÉ, Romeu. Manual de Direito Ambiental. 5. ed. Salvador: Juspodivm, 2015, p. 599), com diferente regulamentação para cada um. De forma a contemplar os "três poderes": "Pessoas poderiam ser condenadas à morte, e em alguns países são, por um procedimento administrativo. Estradas poderiam ser construídas por um colegiado determinando por voto, após discussão, onde cada batida da picareta deveria ser feita. 0 método judicial envolvendo discussão aberta e um procedimento adversarial frente a um júri poderia ser usado para determinar importantes questões de política estrangeira e diplomacia" (VILE, op. cit., p. 380). 
Algumas exceções são estabelecidas como forma de contrabalancear os atores estatais e resguardar a Constituição. No Brasil, por exemplo, a organização das eleições que enquanto atividade majoritariamente administrativa deveria ser incumbida ao Executivo - é conferida ao ramo Judiciário ${ }^{93}$. No Federalist já se podia encontrar a ideia de que organizar eleições é um grande poder, e que por isso deveria ser partilhado - no caso estadunidense, entre Estados-membros e União ${ }^{94}$. Conforme já referido, na Venezuela, esta atividade é incumbida ao "Poder Eleitoral", ramo governamental com status de "Poder", assim como o Legislativo, Executivo e Judiciário.

Contudo, a maior parte das atividades governamentais são, normalmente, atribuições do chamado Poder Executivo, cujas funções multiplicaram-se durante o século $\mathrm{XIX}^{95}$. No Brasil, é o ator estatal responsável por organizar primordialmente as atividades relativas à saúde, educação, segurança pública, dentre outros serviços prestados à população. Cabem ainda tarefas que sustentam o próprio Estado, a exemplo do recolhimento dos tributos necessários para o seu custeio.

Outras atividades mais específicas poderiam ainda ser mencionadas, inclusive em relação à função geral de elaboração de normas abstratas. Por exemplo, existem determinados assuntos que só podem ser regulados por lei se o projeto for iniciado por outro ator estatal que não o Parlamento ${ }^{96}$. Por isso, só a Presidência da República pode, no Brasil, iniciar projeto de lei que fixe ou modifique o efetivo das Forças Armadas ${ }^{97}$. Ou seja, determinada atividade na função de elaboração de normas abstratas cabe apenas a um dos ramos do Estado. A própria elaboração de normas abstratas pode ser feita de outra forma que não o processo legislativo, conforme já referido, através do sistema de criação de precedentes dos tribunais ${ }^{98}$. Órgãos executivos estabelecem regras para a devida implementação de novas leis ${ }^{99}$. O próprio poder dos tribunais de expedir mandados para serem cumpridos por membros do Poder Executivo seria o exercício de

${ }^{93}$ Lei n. 4.737/65 (Código Eleitoral): “Art. 1ํ Este Código contém normas destinadas a assegurar a organização e o exercício de direitos políticos precipuamente os de votar e ser votado. Parágrafo único. O Tribunal Superior Eleitoral expedirá Instruções para sua fiel execução".

94 HAMILTON; JAY; MADISON, op. cit., p. 330. Aponta-se que seria um perigo deixar o "poder sobre as eleições" apenas com os Estados ou somente com a União.

95 VILE, op. cit., p. 6-7. 0 autor afirma que, influenciados pela teoria de Max Weber, houve uma separação entre as funções "políticas" (Regierung/politics) e as "administrativas" (Verwaltung/administration).

${ }^{96}$ CAVALCANTE FILHO, João Trindade. Processo Legislativo Constitucional. Salvador: Juspodivm, 2012 , p. 49.

97 Ibidem, p. 50-51. A referência constitucional é o art. 142.

98 KELSEN, op. cit., p. 389.

99 BELLAMY, op. cit., p. 439.

Revista Publicum

Rio de Janeiro, v.2, n. 2, 2016, p. 120-168

http://www.e-publicacoes.uerj.br/index.php/publicum

DOI: 10.12957/publicum.2016.22787 
poder executivo ${ }^{100}$. Cada "ramo do governo" encontra-se, em maior ou menor grau, engajado em todos os tipos de atividades ${ }^{101}$. Assim, os instrumentos do sistema de freios e contrapesos também podem ser considerados cada qual como um poder a ser exercido ${ }^{102}$.

Outras funções poderiam ser declinadas, a exemplo da "prerrogativa" existente no direito inglês ${ }^{103}$, ou do "Poder Moderador", que foi atribuído ao monarca pela constituição brasileira de $1824^{104}$. Contudo, entende-se que a demonstração feita é suficiente para construir a seguinte ideia: são muitas as atividades governamentais, e elas devem ser distribuídas harmonicamente entre os diversos atores estatais. Não parece haver, portanto, um rol determinado de parcelas do poder estatal as quais é possível agrupar de acordo com uma lógica específica. As funções de elaborar normas abstratas e aplicá-las concretamente podem ser feitas de diversas formas e com variados elementos incidentais.

Uma característica já foi determinada no início do tópico, ao se abordar o conceito de "poder": fazer valer a relação de autoridade, possibilitando a submissão de indivíduos ao que é decidido por aqueles que exercem esta função. A segunda pode ser apontada

100 “E, à Suprema Corte e aos tribunais federais inferiores seguramente foi dado algum poder executivo, como resultado dos seus poderes de emitir mandados (writs of mandamus) a funcionários do executivo federal - algo que apenas a "Court of King's Bench" ou a "Court of Star Chamber" poderia fazer na Inglaterra por causa da ficção de que o Rei era membro da "Court of King's Bench" e do fato de sua participação na "Court of Star Chamber" (CALABRESI, Steven G.; BERGHAUSEN, Mark E.; ALBERTSON, Skylar. The rise and fall of the separation of powers. Northwestern University Law Review, v. 106, n. 2, 2012, p. 535).

101 BELLAMY, op. cit., p. 439. Assim também, Karl Loewenstein, em 1938, analisou diversos governos da época, concluindo que o arranjo de poderes em vários países misturava atividade legislativa e executiva, não podendo corresponder à ideia de separação de poderes, arrematando que "esta conclusão pode parecer heresia para o jurista constitucional tradicional, no entanto ela corresponde às realidades do empirismo do estado moderno" (op. cit., p. 576). 102 GROHMANN, Luís Gustavo Mello. A separação de poderes em países presidencialistas: a América Latina em perspectiva comparada. Revista de Sociologia e Política, n. 17, 2001, p. 86.

103 Locke já fazia referência ao poder que chamou de "prerrogativa", consistente em duas possibilidades que devem ser afeitas ao poder executivo: a de agir discricionariamente em situações de lacuna legislativa, de forma a resolver a situação em prol do bem comum; bem como deixar de aplicar a lei, em situações excepcionais onde a aplicação rigorosa e inflexível dela acarretaria resultados nefastos (op. cit., p. 181-182). A prerrogativa estaria fundamentada na ideia de que o legislador é incapaz de prever e prover leis para tudo que possa ocorrer na sociedade, ou mesmo de antecipar todas as circunstâncias dos fatos que regula (ibidem, p. 181182). Bolingbroke também referia que ao rei da Grã-Bretanha era confiado o poder executivo, além de outros "Poderes e Privilégios", chamados de "Prerrogativas" (op. cit., p. 85). Para o uso atual deste "poder", conferir: REINO UNIDO DA GRÃ-BRETANHA E IRLANDA DO NORTE. Ministério da Justiça. Review of the executive royal prerogative powers: final report. Ministério da Justiça: Londres, 2009, p. 12-27.

${ }^{104}$ LYNCH, Christian Edward Cyril. 0 discurso político monarquiano e a recepção do conceito de poder moderador no Brasil (1822-1824). Revista Dados de Ciências Sociais, Rio de Janeiro, v. 48, n. 3, 2005, p. 638. 
como a importância da função para o quadro político ${ }^{105}$, fazendo com que as atividades que são incumbidas ao órgão sejam institucionalmente relevantes para o sistema de freios e contrapesos ${ }^{106}$.

Neste sentido, havendo a conjugação do elemento subjetivo com o objetivo - ou seja, um órgão hierarquicamente independente, com autonomia administrativa e financeira, e cujas atividades estabeleçam relação de autoridade e tenham relevância para o sistema político, compondo relevantemente o sistema de freios e contrapesos - pode-se dizer que há uma instituição com status de "Poder".

Uma última crítica genérica pode ser feita: em diversos momentos deste texto foram apresentadas alternativas ao termo "Poder" para se referir às entidades, com base em expressões utilizadas pelos autores que iam sendo referenciados: "atores", "departamentos"107, "ramos" (branches) ${ }^{108}$. Este último é o mais utilizado nos Estados Unidos, e parece ser uma opção preferível ao termo "Poderes", por transmitir a ideia de que cada um daqueles órgãos são divisões de um mesmo "tronco", o poder estatal, suplantando a imagem de três poderes que concorrem entre si. Ademais, o vocábulo "Poder" possui diversos significados, pelo que se deve "tanto quanto possível evitar o seu uso" ${ }^{109}$. Contudo, em razão da consagração do termo "Poder" na tradição jurídica brasileira, este ainda será referido.

\section{O Ministério Público como "Quarto Poder" no Brasil}

Do quanto exposto até aqui, é possível apontar que a divisão das atividades estatais em três ramos principais não é a única solução adequada para o balanceamento das funções governamentais. É factível o reconhecimento de outros "Poderes", desde que estejam preenchidos os requisitos subjetivo e objetivo para tanto. Neste sentido, passar-se-á a examinar a viabilidade de tal reconhecimento em relação ao Ministério Público brasileiro,

105 Neste sentido, nos Estados Unidos, consolidou-se a ideia de que a imprensa seria informalmente o "quarto poder", tendo em vista as possibilidades de influência que os veículos de comunicação têm sobre o quadro político. Acerca do tema, destacando a diferença da concepção de "quarto poder" existente para a imprensa no Brasil e nos Estados Unidos: ALBUQUERQUE, Afonso de. Um outro "Quarto Poder": imprensa e compromisso político no Brasil. Contracampo, n. 4, 2000, p. 23-57.

106 “(...) o governo precisa ser limitado internamente pela criação de centros autônomos de poder que irão desenvolver um interesse institucional" (VILE, op. cit., p. 17). Traduziu-se.

107 HAMILTON; JAY; MADISON, op. cit., p. 264.

108 Ibidem, p. 219.

109 VILE, op. cit., p.13. Traduziu-se. Segundo o autor, o termo tem sido utilizado para significar: a posse da habilidade de atingir certos objetivos através da força ou persuasão; a autoridade legal para realizar determinados atos; a função de legislar, executar ou julgar; os ramos do governo; ou as pessoas que compõem estes ramos. 
como "Quarto Poder", postulação esta, inclusive, que não é nem mesmo algo recente, existindo no país há pelo menos cerca de meio século ${ }^{110}$.

A principal objeção à categorização desta entidade como um "Poder" pode ser apontada no art. 2o da Constituição Federal, que faz referência apenas ao "o Legislativo, o Executivo e o Judiciário" como “Poderes da União"111. Evidentemente, o melhor caminho seria que o reconhecimento fosse efetivado mediante emenda constitucional, que estabelecesse simetria entre este dispositivo e o art. 85, II, que relaciona a necessidade de o Presidente da República não atentar contra "o livre exercício do Poder Legislativo, do

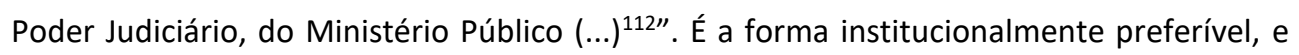
parece ter sido adotada na Constituição argentina de 1994, onde o Ministério Público aparece ao lado do Judiciário, do Executivo e do Legislativo (cada qual constituindo uma "seção" do título "governo federal"113). Mas duas observações podem ser feitas neste ponto, caso não haja iniciativa do Congresso Nacional para assim proceder.

A primeira é que o Poder Constituinte, conforma aponta Canotilho, não pode ser visto como de "caráter onipotente e incondicionado" como formulou Sieyès no século XVIII, tendo em vista que o procedimento constituinte é limitado por "elementos contratuais reais (grupos políticos, religiosos, econômicos, sociais)"114. Neste diapasão, o Poder Constituinte no processo de elaboração das normas estaria obrigado a observar diversas circunstâncias presentes naquela sociedade, a exemplo dos dados relativos à família, propriedade, cultura e comportamento dos indivíduos daquele ambiente social ${ }^{115}$. Não mais é possível oferecer guarida à "teologia política" que caracterizou a Revolução Francesa e que reconhecia ao Poder Constituinte "atributos divinos"116, sendo possível reconhecer que mesmo a Constituição pode apresentar falhas.

Alexy também afirma que a norma constitucional deve corresponder à realidade social, não podendo conduzir a resultados jurídicos não plausíveis; do contrário, sobrevirá

110 Assim, tem-se artigo publicado em 1969, onde se defendia a tese, sustentando o MP funcionar "como um quarto poder - o Poder Fiscalizador" (INACARATO, Márcio Antônio. 0 Ministério Público na ordem jurídico constitucional. Justitia, n. 60, 1999, p. 485).

111 Art. $2^{\circ}$ São Poderes da União, independentes e harmônicos entre si, o Legislativo, o Executivo e o Judiciário.

112 Art. 85. São crimes de responsabilidade os atos do Presidente da República que atentem contra a Constituição Federal e, especialmente, contra: (...) II - o livre exercício do Poder Legislativo, do Poder Judiciário, do Ministério Público e dos Poderes constitucionais das unidades da Federação;

113 Diferentemente, duas outras instituições relevantes, a auditoria geral da nação e o defensor do povo, aparecem vinculadas ao legislativo (como "capítulos").

114 CANOTILHO, J. J. Gomes. Teoria da Constituição e Direito Constitucional. 6. ed. rev. Coimbra: Almedina, 1993, p. 115.

115 Ibidem, p. 115-117.

116 CANOTILHO, J. J. Gomes. Teoria da Constituição e Direito Constitucional. 7. ed. rev. Coimbra: Almedina, 2003, p. 81. 
seu descumprimento ${ }^{117}$. Portanto, também o Constituinte está vinculado aos elementos fáticos. Se o texto traz uma aparente limitação ao reconhecimento do Ministério Público como um "Poder", deve-se notar que, pela análise sistemática, reconhece-se ao órgão esta situação. É inegável que "com a promulgação da Constituição de 1988, o parquet redobrou sua relevância social”118.

Neste sentido, a elaboração do referido dispositivo constitucional (art. 2으) prescindiu de considerar a mudança real da configuração do Ministério Público que foi concretizada no resto do texto. Conferiu-se um grau inegavelmente alto de natureza política ao órgão, às suas funções e aos seus agentes ${ }^{119}$. Este é um dado que não poderia ser ignorado pelo Constituinte.

Outra observação que pode ser feita é que, se à época da elaboração da Constituição não se havia propriamente elementos para reconhecer o Ministério Público como um "Poder", isso não significa que o reconhecimento não possa ser feito atualmente. Contudo, analisando-se posicionamentos recentes do Supremo Tribunal Federal (STF), torna-se possível o reconhecimento judicial de tal situação. Observa-se que, em raras ocasiões, algumas das quais sob o indevido título de "mutação constitucional", o STF tem proferido decisões que contrariam as possibilidades interpretativas dos dispositivos constitucionais, com base em novos entendimentos ${ }^{120}$. Mais recentemente, a Corte parece ter utilizado do mesmo raciocínio no Habeas Corpus n. 126.292/SP, acerca da presunção de inocência e pendência de recurso para os tribunais superiores ${ }^{121}$.

117 ALEXY, Robert. Teoria dos Direitos Fundamentais. 2. ed. Virgílio Afonso da Silva (trad.). São Paulo: Malheiros, 2011, p. 140-141. No caso em questão, o autor faz referência a um caso julgado pelo Tribunal Constitucional alemão e que envolvia o tema relativo à escolha profissional no âmbito do funcionamento das farmácias.

118 CUNHA JR., op. cit., p. 1138.

119 Ibidem, p. 1138.

120 CAMARGO, Margarida Maria Lacombe. Prefácio. In: RAMOS, Carlos Henrique. Mutação constitucional: constituição e identidade constitucional evolutiva. Curitiba: Juruá, 2013, p. 1314. A autora aponta três casos recentes: "a Rcl 4335, que procura conferir efeito erga omnes ao resultado do julgamento do HC 82.959, esvaziando a regra do artigo 52, X, da Constituição; a ADI 4277 e a ADPF 132, que procuraram o reconhecimento da união entre pessoas do mesmo sexo como entidade familiar; e a AP 470, na parte em que se busca relativizar o $§ 2^{\circ}$ do artigo 55 da Constituição". Contudo, discorda-se no ponto em que a autora parece reconhecer haver mutação constitucional nos casos citados, tendo em vista que, em verdade, não há atribuição de uma nova norma possível a um texto já existente, que caracterizaria o instituto, mas sim alteração informal do texto, sem haver referência a instituto jurídico que a autorizaria. Neste sentido: RAMOS, Carlos Henrique. Mutação constitucional: constituição e identidade constitucional evolutiva. Curitiba: Juruá, 2013, p. 245-246, comentando o julgamento da referida Reclamação 4335.

121 Entende-se que, diante do texto constitucional que menciona expressamente haver presunção de inocência "até o transito em julgado", a opção seria mudar a conformação constitucional do princípio da não culpabilidade, suprimindo a expressão por outras similares às das Cartas de Direitos Humanos das quais o Braisl é signatário. A Convenção Americana, por exemplo, estabelece que a presunção de inocência existe "enquanto não se comprove legalmente sua culpa" (art. 8ํㅜ, 2). Este texto parece se coadunar com a interpretação de que tal 
Portanto, malgrado o ideal seja a alteração por emenda constitucional, é possível que, ao resolver uma situação colocada à apreciação dos tribunais no qual esta tese seja relevante, haja o reconhecimento do status de "Poder" do Ministério Público. Poder-se-ia objetar que tal atitude implicaria violação aos limites materiais de reforma, em relação à separação dos poderes (art. 60, §4으, III) ${ }^{122}$, o que não poderia ser atingido nem mesmo por emenda constitucional. Contudo, conforme já foi exposto, não se estaria alterando o balanço das instituições que já existe na Constituição. Pelo que foi analisado no primeiro tópico acerca da necessidade de repartição das funções estatais, o dispositivo mencionado parece visar à proteção contra a acumulação de funções, a concentração de poder que leva perigo à liberdade, e não impedir o contrabalanceamento das instituições.

Também em relação à Constituição dos Estados Unidos é possível constatar que a adoção do termo "Poder Executivo" cria uma situação de dissonância com a realidade, vindo Vile a apontar que o termo "executivo" há muito tempo já perdeu seu sentido original, seja quando o mesmo passou a estar altamente envolvido na atividade política legislativa, seja posteriormente, em razão da hipertrofia da máquina administrativa que acaba não estando exatamente ao controle do líder político ${ }^{123}$. Assim, para o autor, haveria quatro seções principais do Estado: o Legislativo, o Governo, a Máquina Administrativa e o Judiciário, embora também existente a dificuldade de tal reconhecimento por causa da redação do texto constitucional ${ }^{124}$. Em razão desta dissonância, as tentativas da Suprema Corte estadunidense de controlar os mecanismos de prevenção de abuso de poder com base em um modelo teórico tripartite estariam sendo "uma tarefa impossível"125.

O suposto impedimento existente no art. 2o da CF também não se mostra suficiente quando se analisa outro fato da realidade constitucional. Existe inegavelmente uma instituição com status de "Poder" e que não se encontra declinada no dispositivo referido: o Poder Constituinte Reformador. Conforme a teoria constitucional, este é um poder constituído e limitado pela Constituição ${ }^{126}$, estando sujeito ao controle exercido pelo Judiciário ${ }^{127}$. Embora no Brasil este poder seja exercido pelo Congresso Nacional ${ }^{128}$,

comprovação ocorre nas instâncias ordinárias, tendo em vista que uma análise sistemática mostra que a Convenção, neste ponto, não utilizou o termo "sentença passada em julgado", como o fez em outro dispositivo (art. 10), ao se referir à indenização.

122 Art. 60. A Constituição poderá ser emendada mediante proposta: (...) § 4oNão será objeto de deliberação a proposta de emenda tendente a abolir: (...) III - a separação dos Poderes;

123 VILE, op. cit., p. 400.

124 Ibidem, p. 400.

125 Ibidem, p. 400.

126 MENDES, Gilmar Ferreira; BRANCO, Paulo Gustavo Gonet. Curso de direito constitucional. 9. ed. São Paulo: Saraiva, 2014, p. 118

127 Ibidem, p. 125-126. 
deve-se destacar que a função legislativa não é a mesma de promover a reforma constitucional $^{129}$. Portanto, malgrado normalmente seja exercido pelo órgão que corresponde ao "Poder Legislativo", é possível que um país defina que as alterações à constituição apenas possam ser feitas por órgão especial destinado somente a este fim ${ }^{130}$.

Ademais, a própria Constituição reconheceu textualmente a existência dos Poderes Constitucionais das unidades da Federação, os quais não podem ter seu livre exercício obstado $^{131}$. É certo que tais Poderes também devem estar em harmonia com os demais, em que pese não tenham sido declinados expressamente no art. 2‥ Ou seja, o reconhecimento do Ministério Público como um "Poder", a despeito do art. 2o da CF, não seria nem mesmo algo sem precedente no direito constitucional brasileiro. Feita a constatação quanto à possibilidade de se reconhecer outros "Poderes" neste âmbito ainda que haja uma dificuldade de cunho cultural $^{132}$-, passa-se a apontar os referidos elementos subjetivo e objetivo referente à instituição.

Em relação ao elemento subjetivo, a constatação quanto à existência é algo simples. A Constituição de 1988 previu o Ministério Público no capítulo "das funções essenciais à justiça", aparte daqueles referentes ao Executivo, Legislativo ou Judiciário. Estabeleceu a unidade da instituição, ainda que mantendo a independência funcional (art. $127, \S 1^{133}$ ). Assegurou a autonomia administrativa e financeira (art. 127, §§ 2으 e 3ํ134) e previu a existência de chefias indicadas pelo Executivo e aprovadas pelo Legislativo (art. $128, \S \S 1$ 으 e $\left.3^{135}\right)$. Determinou o gozo das mesmas garantias institucionais conferidas aos

${ }^{128}$ Art. 60. A Constituição poderá ser emendada mediante proposta: (...) § 2º A proposta será discutida e votada em cada Casa do Congresso Nacional, em dois turnos, considerando-se aprovada se obtiver, em ambos, três quintos dos votos dos respectivos membros.

129 MAGALHÃES, op. cit., p. 96.

130 KELSEN, op. cit., p. 369-370.

131 Art. 85. São crimes de responsabilidade os atos do Presidente da República que atentem contra a Constituição Federal e, especialmente, contra: (...) II - o livre exercício do Poder Legislativo, do Poder Judiciário, do Ministério Público e dos Poderes constitucionais das unidades da Federação;

132 Em sentido próximo: VILE, op. cit., p. 11. 0 autor afirma "não estarmos preparados" para visualizar o governo nem como uma só estrutura monolítica, nem como uma aglomeração de relações pragmáticas.

133 Art. 127. O Ministério Público é instituição permanente, essencial à função jurisdicional do Estado, incumbindo-lhe a defesa da ordem jurídica, do regime democrático e dos interesses sociais e individuais indisponíveis.

$\S 1$ 을 São prípios institucionais do Ministério Público a unidade, a indivisibilidade e a independência funcional.

134 Art. 127 (...) § 2을 Ao Ministério Público é assegurada autonomia funcional e administrativa, podendo, observado o disposto no art. 169, propor ao Poder Legislativo a criação e extinção de seus cargos e serviços auxiliares, provendo-os por concurso público de provas ou de provas e títulos, a política remuneratória e os planos de carreira; a lei disporá sobre sua organização e funcionamento. § 3o 0 Ministério Público elaborará sua proposta orçamentária dentro dos limites estabelecidos na lei de diretrizes orçamentárias.

135 Art. 128. 0 Ministério Público abrange (...) § 1o O Ministério Público da União tem por chefe o Procurador-Geral da República, nomeado pelo Presidente da República dentre integrantes da 
juízes (art. 128, §5ำ ${ }^{136}$, notadamente a vitaliciedade, que há séculos é reconhecida como o principal elemento para prover a independência do Judiciário ${ }^{137}$.

Complementarmente, o STF pacificou o entendimento de que membros do Ministério Público não podem exercer cargos no Executivo, ainda que haja autorização da instituição, por estabelecer subordinação a outro Poder, com capacidade para elidir a imparcialidade do Ministério Público ${ }^{138}$. Neste sentido, há uma instituição organicamente estruturada que possui os caracteres que permitiriam, em havendo o elemento objetivo, o reconhecimento da existência de um "Poder".

Em relação a este último parâmetro, foi referido anteriormente que ele reputar-seia verificado caso o órgão estatal exercesse funções que estabelecessem relação de autoridade e fossem relevantes para o sistema político e o funcionamento dos mecanismos de freios e contrapesos. Esta situação passará a ser examinada.

Historicamente, o poder de acusar passou por diversas transformações, especialmente quanto à titularidade. Na Grécia Antiga, em muitos Estados a acusação era pública e prerrogativa de qualquer cidadão ${ }^{139}$. Contudo, em razão das possibilidades devastadores de um tal poder vir a ser exercido injustamente, foram estabelecidas leis em defesa do indivíduo; em Atenas, por exemplo, o acusador que não conseguisse convencer ao menos um quinto dos votantes era condenado a uma sanção pecuniária ${ }^{140}$.

carreira, maiores de trinta e cinco anos, após a aprovação de seu nome pela maioria absoluta dos membros do Senado Federal, para mandato de dois anos, permitida a recondução (...) § $3^{0}$ Os Ministérios Públicos dos Estados e o do Distrito Federal e Territórios formarão lista tríplice dentre integrantes da carreira, na forma da lei respectiva, para escolha de seu ProcuradorGeral, que será nomeado pelo Chefe do Poder Executivo, para mandato de dois anos, permitida uma recondução.

${ }^{136}$ Art. 128 (...) § 5ำ Leis complementares da União e dos Estados, cuja iniciativa é facultada aos respectivos Procuradores-Gerais, estabelecerão a organização, as atribuições e o estatuto de cada Ministério Público, observadas, relativamente a seus membros: I - as seguintes garantias: a) vitaliciedade, após dois anos de exercício, não podendo perder o cargo senão por sentença judicial transitada em julgado; b) inamovibilidade, salvo por motivo de interesse público, mediante decisão do órgão colegiado competente do Ministério Público, pelo voto da maioria absoluta de seus membros, assegurada ampla defesa; c) irredutibilidade de subsídio, fixado na forma do art. 39, § 4\% , e ressalvado o disposto nos arts. 37, X e XI, 150, II, 153, III, 153, § 2으. I.

137 "Tanto tecnicamente quanto psicologicamente o dispositivo para alcançar independência foi a vitaliciedade dos magistrados, outro presente do gênio político anglo-saxão para o estado moderno" (LOEWENSTEIN, op. cit., p. 570". Traduziu-se. Ou ainda: "Se, então, os tribunais de justiça hão de ser considerados os baluartes de uma constituição limitada contra usurpações do legislativo, esta consideração irá fornecer um forte argumento para a vitaliciedade dos órgãos judiciais, já que nada mais irá contribuir tanto quanto isso para o espírito independente nos juízes que deve ser essencial para a fiel performance de um dever tão árduo" (HAMILTON; JAY; MADISON, op. cit., p. 431-432). Traduziu-se.

138 STF. Tribunal Pleno. ADPF 388. Rel. Min. Gilmar Mendes. Julg. 09.03.2016.

139 MONTESQUIEU, op. cit., p. 243.

140 Ibidem, p. 243. 0 autor fornece outros exemplos de formas de contrabalancear a acusação: "Em Roma, o acusador injusto era notado com infame; imprimiam-lhe a letra K sobre a fronte. Montava-se guarda ao acusador, para que este ficasse impossibilitado de corromper os juízes ou as testemunhas". 
Na Roma Antiga, houve um tempo onde era permitido a qualquer cidadão acusar outro - possibilidade calcada no entendimento de que cada um deveria demonstrar o zelo pela coisa pública ${ }^{141}$. Contudo, tal disposição originava situações indesejáveis, pois "Qualquer indivíduo que possuísse muitos vícios e muitos talentos, uma alma bem baixa e um espírito ambicioso, procurava um criminoso, cuja condenação pudesse agradar ao príncipe; era essa a estrada que conduzia às honrarias e à fortuna" ${ }^{142}$. Em determinados casos, somente o Legislativo deveria funcionar como acusador ${ }^{143}$. Nestas situações, os "tribunais da lei", que Ihe seriam inferiores, não teriam a possibilidade de julgar devidamente, pois "seriam arrastados pela autoridade de um tão grande acusador" 144 . Assim, para preservar a segurança do particular, deveria haver a acusação pela parte legislativa composta pelo povo perante a parte legislativa composta pelos nobres, aos quais caberiam o julgamento, configurando abuso se fosse o povo ao mesmo tempo juiz e julgador $^{145}$.

Na Idade Média, em muitas situações a mera acusação já tinha consequências terríveis para o indivíduo, sendo exigida a colaboração forçada do acusado e não lhe sendo permitido o contraditório ${ }^{146}$. Por esta razão, Montesquieu admirava a lei de sua época, a qual exigia que o monarca designasse um oficial em cada tribunal para que processasse os crimes em seu nome, promovendo assim a execução das leis ${ }^{147}$. O autor francês sinalizava, ainda, para o cuidado que se deve tomar em relação à acusação de determinados crimes - aqueles que sejam relativos mais às ideias que se formam acerca do caráter de um cidadão do que os delitos que se dirijam mais diretamente a ações -, tendo em vista que este ato "poderá ferir extremamente a liberdade, e tornar-se a origem de uma infinidade de tiranias, se o legislador não souber limitá-la" ${ }^{148}$. Tornava possível “ao crime do mundo mais incerto (...) juntar provas as mais incertas" ${ }^{149}$.

Como a acusação é um poder com muitos perigos, mesmo nos Estados absolutistas, cabendo o papel da acusação ao monarca, não poderia ser ele também o juiz

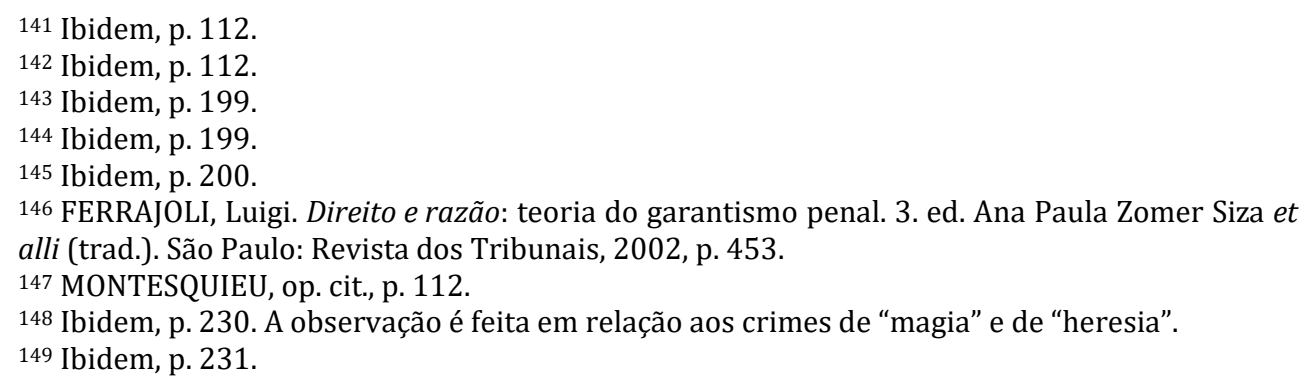


da causa ${ }^{150}$. Assim que, ao analisar o processo de impeachment, o Federalist faz referência ao poder de "promover o impedimento"151. À Câmara dos Representantes caberia o "direito de acusar", ao passo que o Senado seria incumbido do "direito de julgar"152. O fundamento desta separação é evitar fazer das mesmas pessoas, ao mesmo tempo, acusadores e julgadores, resguardando contra o perigo de uma persecução onde prevaleça o "espírito tendencioso" em ambas as casas ${ }^{153}$.

Atualmente, ainda que não se verifiquem institucionalizadas as barbáries de outras épocas relativas ao acusado, é possível afirmar que o mero fato de ser réu em um processo criminal já é "uma pena em si mesmo", com diversas possíveis consequências danosas $^{154}$. Neste sentido, tem-se que o poder de acusar é, inegavelmente, o exercício de uma relação de autoridade, algumas vezes até com consequências práticas de grande impacto para o sistema político. Veja-se que o mero fato de estar sendo processado criminalmente - ainda que existam freios relevantes para evitar tal situação ${ }^{155}$ - é suficiente para afastar por até cento e oitenta dias o maior cargo da República, o de Presidente (art. 86, $\S 1$ ㅇำ ${ }^{156}$.

A promoção privativa da ação penal pública traduz-se, seguramente, no recebimento de parcela do poder uno estatal, de exercício da soberania ${ }^{157}$. Pode-se objetar que tal atividade não seria suficiente para fundamentar a relevância a ponto de ser considerado um "Poder". Mas também o Judiciário já foi tido como "nulo" por Montesquieu. Consideração próxima a esta foi feita no Federalist, onde se afirmou que o Judiciário era o "menos perigoso", por sua pouca capacidade de causar danos para alguém ${ }^{158}$ Não possuindo o comando do Exército, como o Executivo, nem das finanças, como o Legislativo, até mesmo a eficácia de seus julgamentos dependem do apoio do

150 “Nos Estados monárquicos, o príncipe é a parte que processa os acusados e os faz punir ou absolver; se ele julgasse por si próprio, seria ele ao mesmo tempo o juiz e a parte" (Ibidem, p. 109).

151 HAMILTON; JAY; MADISON, op. cit., p. 361. Traduziu-se.

152 Ibidem, p. 365. Traduziu-se

153 Ibidem, p. 365. Traduziu-se

154 LOPES JR. Aury. Sistemas de investigação preliminar no processo penal. Rio de Janeiro: Lumen Juris, 2001, p. 48-54.

155 Pelo art. 86 da Consituição Federal é necessária a autorização de dois terços da Câmara dos Deputados e o recebimento da peça acusatória pelo Supremo Tribunal Federal.

156 Art. 86 (...)§ 1ำ 0 Presidente ficará suspenso de suas funções: I - nas infrações penais comuns, se recebida a denúncia ou queixa-crime pelo Supremo Tribunal Federal;

157 BURLE FILHO, José Emmanuel. O Ministério Público e sua posição Constitucional. Justitia, n. 60,1999 , p. 1060. Também salientando que o Ministério Público tem uma parcela direta da soberania do Estado: MAZZILLI, Hugo Nigro. O Ministério Público no processo penal. Justitia, n. 60, 1999, p. 665.

158 HAMILTON; JAY; MADISON, op. cit., p. 428. Traduziu-se. 
Executivo, pelo que seria o "mais fraco" dos três "ramos" do governo ${ }^{159}$, sendo tido como um fruto do Executivo ${ }^{160}$.

Contudo, ao se indicar para o Poder Judiciário a possibilidade de exercer o controle de constitucionalidade dos atos legislativos, tendo em vista que a interpretação das leis é sua competência, e que a constituição nada mais é do que uma "lei fundamental" 161 , este poder ganhou maior importância do que se pensava para ele à época, especialmente em relação à teoria de Montesquieu, atingindo patamar que por vezes supera o processo político ordinário ${ }^{162}$. Atualmente, em uma sociedade marcada pelo cometimento de ilícitos, inclusive com casos reiterados de condenações e abertura de processos criminais contra diversos ocupantes dos mais altos cargos do Executivo e do Legislativo Federal, certamente o poder acusatório ganha um relevo maior do que costumava ter.

Ademais, há ainda o outro lado da moeda, de importância talvez até maior, porque a decisão final caberá à própria instituição: o poder conferido ao Ministério Público de não processar alguém criminalmente (art. 28 do Código de Processo Penal ${ }^{163}$ e art. 3ㅇ, I, da Lei n. 8.038/90, que trata dos procedimentos perante o STF e STJ ${ }^{164}$ ). Ou seja, mesmo com fortes elementos indicativos da ocorrência de crime, se a instituição entender em sentido diverso, não há como ocorrer punição penal contra o indivíduo.

Bastariam as situações já relatadas para colocar o Ministério Público como um "Poder" constitucional. Contudo, é comum que, além de uma função precípua, cada "Poder" seja atribuído com outras funções, de modo a reforçar a harmonia em relação aos demais $^{165}$. Dentro desta ideia, a Constituição Federal conferiu diversas outras funções ao Ministério Público: indicar membros para a composição dos Tribunais (art. 94); ajuizar dissídio coletivo do trabalho em determinadas situações (art. 114, §3ㅇ); zelar pelos serviços de relevância pública (art. 129, II); promover o inquérito civil e a ação civil pública

159 Ibidem, p. 428. Traduziu-se.

160 Ibidem, p. 266. Traduziu-se.

161 Ibidem, p. 430. Traduziu-se.

162 BELLAMY, op. cit., p. 436.

163 Art. 28. Se o órgão do Ministério Público, ao invés de apresentar a denúncia, requerer o arquivamento do inquérito policial ou de quaisquer peças de informação, o juiz, no caso de considerar improcedentes as razões invocadas, fará remessa do inquérito ou peças de informação ao procurador-geral, e este oferecerá a denúncia, designará outro órgão do Ministério Público para oferecê-la, ou insistirá no pedido de arquivamento, ao qual só então estará o juiz obrigado a atender.

164 Tem-se: "Art. 3o - Compete ao relator: I - determinar o arquivamento do inquérito ou de peças informativas, quando o requerer o Ministério Público, ou submeter o requerimento à decisão competente do Tribunal". O STF, contudo, ressalva que esta possibilidade diz respeito ao entendimento acerca da falta de elementos. Se o pedido for por atipicidade da conduta ou extinção de punibilidade, poderá o Tribunal examinar o mérito (STF. Tribunal Pleno. Pet. 3.927/SP. Rel. Min. Gilmar Mendes. Julg. 12.06.2008. DJe. 17.10.2008.

165 BARROSO, Luís Roberto. Curso de Direito Constitucional Contemporâneo: os conceitos fundamentais e a construção do novo modelo. 4. ed. São Paulo: Saraiva, 2013, p. 197. 
(art. 129, III); defender os interesses das populações indígenas (art. 129, V); exercer o controle externo da atividade policial (art. 129, VII), dentre outras, inclusive atribuíveis por lei (art. 128, §5으).

Para além, outras funções foram incumbidas ao Procurador-Geral da República: representar pela intervenção da União nos Estados em determinadas situações (art. 36, IV); realizar atividades tipicamente administrativas, mediante delegação do Presidente da República (art. 84, parágrafo único); propor ações para o controle concentrado de constitucionalidade (art. 103, VI); opinar nos processos de competência do STF (art. 103, $\S 1$ )); participar da seleção de alguns membros (art. 103-B, X e XI) e oficiar junto ao Conselho Nacional de Justiça (art. 103-B, §6)); suscitar incidente de deslocamento de competência em caso de grave violação de direitos humanos (art. 109, §5ㅇ); presidir o Conselho Nacional do Ministério Público (art. 130-A, I).

Percebe-se que a maior parte das funções acima referidas não são essenciais à instituição, podendo haver modificação; por exemplo, a atribuição à Defensoria Pública da defesa dos interesses das populações indígenas. Mas estas funções são acrescidas como forma de equilibrar a participação política dos Poderes - inclusive, a constatação de que tantas funções foram atribuídas ao órgão é mais um argumento a corroborar com o status de "Poder" que a Constituição atribui ao Ministério Público.

Pelo que foi exposto até aqui, não se concorda com a ideia de que o Ministério Público representaria uma "nova função", a de "defensor da ordem jurídica"166, ou que a "função" primordial que permitiria o reconhecimento do Ministério Público como um "Poder" seria a de "fiscalizador" 167 ou de "controlador". O controle das atividades governamentais pelo próprio Estado é efetuado a partir do sistema de freios e contrapesos, da organização dos atores públicos uns em relação aos outros, de forma a prevenir que um dos componentes do mecanismo de controle torne-se o "controlador"168. Soma-se a isso a ideia de que a atividade de fiscalização deve envolver o povo como um todo, os grupos de pressão, de mídia, as organizações civis ${ }^{169}$, tendo em vista que "O controle do governo nunca pode ser um canal só de ida, pois isso sempre significará que um grupo de pessoas ganhará controle sobre os outros" 170 .

166 Como afirmando, contrariamente, em: BURLE FILHO, op. cit., p. 1060.

167 Como é feito em: INACARATO, op. cit., p. 485.

168 VILE, op. cit., p. 365. Vale lembrar, neste sentido, que por séculos tem-se expressamente reconhecido ao Poder Legislativo a função fiscalizatória (MORAES, Alexandre de. Limitações constitucionais às comissões parlamentares de inquérito. Revista de Informação Legislativa, n. 146, 2000, p. 281).

169 VILE, op. cit., p. 362-365. Neste sentido, o autor afirma que o sistema de freios e contrapesos também deve envolver estes atores (ibidem, p. 366).

170 Ibidem, p. 365-366. 
Assim, todos os Poderes devem exercer fiscalização uns dos outros, de acordo com o desenho constitucional e possibilidades daí decorrentes. Ademais, tentar atribuir ao Ministério Público esta função, que é a essência do sistema de freios e contrapesos, poderia dissipar o imperativo de que também esta instituição deve ser fiscalizada, tendo em vista que nenhum poder está imune à tentação de usurpar atribuições dos demais. E, conforme será demonstrado, o Ministério Público já utilizou de sua proeminência constitucional para promover não a defesa da ordem jurídica, conforme exposto no art. 127 da CF, mas seus próprios interesses institucionais. Se tais condutas não devem ser perpetradas por quaisquer dos Poderes, menos ainda sob o título de "defesa da ordem jurídica". As instituições são corporificadas por pessoas, às quais a tentação à exacerbação de poder é algo constantemente presente.

Há quem negue a possibilidade de reconhecimento do status de "Poder" ao Ministério Público sob o argumento de que, caso isso ocorresse, dever-se-ia também fazêlo em relação a outros órgãos institucionais dotados de autonomia, a exemplo da Defensoria Pública e do Tribunal de Contas ${ }^{171}$. Ora, se se entende que tais órgãos possuem os mesmos elementos caracterizadores que o Ministério Público, nada impede que haja o reconhecimento ${ }^{172}$. Contudo, não sendo esta análise voltada a estas instituições, não serão feitas maiores considerações. O que não se vê sentido é na alegação de que o Ministério Público está alheio aos três Poderes, tem elementos análogos a estes, exerce função própria, mas não está alçado à mesma categoria ${ }^{173}$.

Assim, malgrado o texto constitucional não tenha mencionado expressamente a existência de um “Quarto Poder", em essência, é possível observá-lo ${ }^{174}$. O que se percebe em diversos países é que as últimas décadas foram marcadas pela existência de "novas

171 LOPES, João. 0 Ministério Público e o quarto Poder. Revista Jus Navigandi, n. 3516, 15 fev. 2013. Disponível em: <https://jus.com.br/artigos/23730>. Acesso em: 06 mai. 2016.

172 Há quem entenda neste sentido: "A efetiva autonomia especial do Ministério Público, que o transforma em um poder de fiscalização, precisa ser estendida ao Tribunal de Contas e à Defensoria Pública, caracterizando, desta forma, um poder de fiscalização necessário para enfrentar as complexidades do Estado contemporâneo" (MAGALHÃES, op. cit., p. 95). Seguindo nesta direção, embora sem fazer o reconhecimento de que o Tribunal de Contas seria um "poder", tem-se a posição de Carlos Ayres Britto: “(...) o Tribunal de Contas da União não é órgão do Congresso Nacional, não é órgão do Poder Legislativo. Quem assim me autoriza a falar é a Constituição Federal, com todas as letras do ser art. 44, litteris: 'O Poder Legislativo é exercido pelo Congresso Nacional, que se compõe da Câmara dos Deputados e do Senado Federal'. Logo, o Parlamento brasileiro não se compõe do Tribunal de Contas da União" (0 regime constitucional do Tribunal de Contas. Revista do Tribunal de Contas do Estado do Rio de Janeiro, v. 2, n. 8, 2014, p. 11).

1730 reconhecimento de cada um destes elementos e a discordância quanto a posição de "poder" pode ser vista em: BURLE FILHO, op. cit., p. 1059-1060.

174 MAGALHÃES, op. cit., p. 96-67. Contudo, o autor, diferentemente do que é exposto aqui, faz referência à existência do poder fiscalizatório, que abrangeria Ministério Público, Defensoria Pública e Tribunal de Contas. 
tendências no desenvolvimento institucional" que dificilmente são encaixáveis nas categorias tradicionais do arranjo funcional do Estado ${ }^{175}$. Em antiga afirmação de Alfredo Valladão: “O Ministério Público se apresenta com a figura de um verdadeiro poder do Estado. Se Montesquieu tivesse escrito hoje o Espírito das Leis, por certo não seria tríplice, mas quádrupla, a Divisão dos Poderes"176. Portanto, ao Ministério Público deve ser reconhecida esta situação.

\section{Relevância prática de reconhecer o Ministério Público como}

\section{"Quarto Poder"}

Há quem entenda que a discussão sobre ser o Ministério Público um "Quarto Poder" não tem justificativa, bastando que se reconheça seu caráter de órgão independente ${ }^{177}$. Pela lógica pura poderia ser, reiterando-se o entendimento aqui adotado de que no Estado existem órgãos independentes, com características e atribuições que se limitam reciprocamente $^{178}$, não sendo nem mesmo necessário que cada ramo governamental possua atividades diferentes em essência, mas sim que haja um contrabalanceamento pelos outros, com um dos atores tendo a decisão final ${ }^{179}$.

Contudo, conforme também já referido, em razão da influência até os dias atuais do pensamento constitucional do século XVIII, o reconhecimento de ser o Ministério Público um "Poder" tem uma eficácia argumentativa que escapa ao rigor lógico, possibilitando atrair atenção para ao menos duas situações relevantes: o Ministério Público também compõe o sistema de freios e contrapesos, pelo que o ordenamento jurídico pode estabelecer previsões de que a instituição interfira nas atividades das demais, bem como que estas intervenham em suas funções ${ }^{180}$. Em razão disso, novas

175 VILE, op. cit., p. 347.

176 VALLADÃO, Alfredo. O Ministério Público. Rio de Janeiro: Freitas Bastos, 1973, p. 27 apud GARCIA, Emerson. Ministério Público: organização, atribuições e regime jurídico. 5. ed. São Paulo: Saraiva, 2015, p. 107.

177 GARCIA, Emerson, op. cit., p. 106; MAZZILLI, Hugo Nigro. O Ministério Público e Constituinte. Justitia, n. 60, 1999, p. 989.

178 “Com a evolução do Estado moderno, percebemos que a ideia de tripartição de poderes se tornou insuficiente para dar conta das necessidades de controle democrático do exercício do poder, sendo necessário superar a ideia de três poderes para se chegar a uma organização de órgãos autônomos reunidos em mais funções do que as três originais" (MAGALHÃES, op. cit., p. 95).

179 CLAUS, op. cit., p. 426.

180 Neste sentido, embora de forma mais genérica, tem-se a afirmação de Michel Temer: “Eu vejo como é importante dizer que Ministério Público é o quarto Poder, assim construímos nosso Estado democrático de Direito", segundo reportagem em: ASSOCIAÇÃO NACIONAL DOS 
configurações do sistema são sempre possíveis ${ }^{181}$. Além disso, o Ministério Público, enquanto "Poder" da República, deve exercer sobre si uma autocontenção, de modo a não usurpar funções dos demais "Poderes", sob pena de desarranjo constitucional. Estas situações serão abordadas em seguida.

Um esclarecimento, contudo, é necessário: aos temas a serem desenvolvidos caberia o desenvolvimento de uma investigação autônoma, de maior fôlego do que a que se pretende realizar. O objetivo certamente não é apresentar todas as minúcias e argumentos sobre cada um dos tópicos, mas sim pontuar situações às quais permitem proceder à demonstração que se pretende.

\subsection{O Ministério Público integra o sistema de freios e contrapesos}

Uma decorrência do reconhecimento do Ministério Público como um "Poder" é a maior visibilidade quanto ao fato de que a instituição também integra o sistema de freios e contrapesos. Embora esta observação pareça trivial, poucas vezes ela é levada em consideração em debates relevantes que envolvem a possibilidade de atuação de outros ramos governamentais nas atividades do Ministério Público, bem como do caminho inverso.

Serão examinadas algumas questões - ainda que sem aprofundar o mérito de cada uma delas - nas quais esta constatação, embora de potencial relevância, não costuma ser levada em consideração. Talvez este fato ocorra não só pela não visualização do Ministério Público como um "Poder", mas também em razão de serem situações reguladas por norma infraconstitucional. Isto, contudo, não deve ser motivo para desconsideração, tendo em vista que os mecanismos do sistema de freios e contrapesos não necessariamente estão na Constituição, podendo haver regulação por lei ordinária ${ }^{182}$, desde que não já exista regulação exaustiva naquela.

PROCURADORES DA REPÚBLICA. Ministério Público é o quarto Poder, afirma Temer, 04 nov. 2009. Disponível em: <http://anpr.org.br/noticia/1832>. Acesso em 07 mai. 2016.

181 Neste sentido, seguindo o que já foi aqui referido: “(...) apenas haverá violação à cláusula pétrea da separação dos Poderes se o seu conteúdo nuclear de sentido tiver sido afetado" (BARROSO, op. cit., p. 197).

182 Esta característica é ainda mais marcante em constituições sintéticas como a dos Estados Unidos, havendo o aprimoramento do sistema de freios e contrapesos mais por leis do que por emendas constitucionais. Por exemplo, as várias décadas de envio de tropas ao estrangeiro pelos presidentes dos Estados Unidos sem autorização do Congresso resultou no "War Powers Act", aprovado em 1973 (VILE, op. cit., p. 408). No Brasil, basta fazer referência ao fato de que instrumentos importantíssimos de balanceamento de poder estão previstos em lei, a exemplo do quórum para modulação dos efeitos das decisões do STF no controle concentrado, tendo tal instrumento "rompido com a tradição de declarar nula a lei inconstitucional" (CAMPOS, Carlos Alexandre de Azevedo. Explicando o avanço do ativismo judicial do Supremo Tribunal Federa. 


\subsubsection{Arquivamento nos procedimentos criminais}

Talvez o assunto mais importante ao qual esta constatação tem aplicação prática é o referente às possibilidades de discordância entre o órgão julgador e o órgão acusador, seja no pedido de arquivamento, seja em demais fases do processo.

Segundo dispõe o art. 28 do Código de Processo Penal, se o órgão do Ministério Público requerer o arquivamento das peças de investigação, o juiz pode discordar, ao que haverá a remessa para o Procurador-Geral, a quem caberá a decisão final ${ }^{183}$. Há quem entenda que esta disposição é incompatível com a Constituição Federal de 1988, por violar o princípio acusatório e representar uma intervenção do Judiciário, devendo o órgão julgador atender ao pleito formulado ${ }^{184}$.

Contudo, deve-se notar, conforme já referido, que a possibilidade de intervenção de um poder no outro, desde que de forma limitada, para exercer algum tipo de controle, é a essência do sistema de freios e contrapesos ${ }^{185}$. O questionamento constitucional do art. 28 não pode prescindir da superação da divisão estanque da teoria de Montesquieu que, conforme assenta Virgílio Afonso da Silva, "não faz mais sentido há muito tempo"186.

Ao defender a inconstitucionalidade do art. 28, costuma-se fazer analogia com o inquérito civil, o qual, em caso de arquivamento, é diretamente remetido ao Conselho Superior ${ }^{187}$. Esta comparação, contudo, não parece cabível - ainda que se entenda, aqui, que a proposta é viável. Isto porque as questões não criminais podem ser levadas à apreciação do Judiciário por diversos legitimados, inclusive não estatais ${ }^{188}$, ao passo que a

In: FELLET, André; NOVELINO, Marcelo (org.). Constitucionalismo e democracia. Salvador: Juspodivm, 2013?, p. 374).

183 Art. 28. Se o órgão do Ministério Público, ao invés de apresentar a denúncia, requerer o arquivamento do inquérito policial ou de quaisquer peças de informação, o juiz, no caso de considerar improcedentes as razões invocadas, fará remessa do inquérito ou peças de informação ao procurador-geral, e este oferecerá a denúncia, designará outro órgão do Ministério Público para oferecê-la, ou insistirá no pedido de arquivamento, ao qual só então estará o juiz obrigado a atender.

184 MARTELETO FILHO, Wagner. Sistema acusatório e garantismo: uma breve análise das violações do sistema acusatório no Código de Processo Penal. De jure, Belo Horizonte, n. 12, 2009, p. 211-212.

185 MAGALHÃES, op. cit., p. 94.

186 SILVA, Virgílio Afonso da. Interpretação Constitucional e Sincretismo Metodológico. In: SILVA, Virgílio Afonso da (org.). Interpretação Constitucional. São Paulo: Malheiros, 2007, p. 130.

187 MARTELETO FILHO, op. cit., p. 212.

188 Dispõe a Lei n. 7.347/85 (Lei de Ação Civil Pública): “Art. 50 Têm legitimidade para propor a ação principal e a ação cautelar: I - o Ministério Público; II - a Defensoria Pública; III - a União, os Estados, o Distrito Federal e os Municípios; IV - a autarquia, empresa pública, fundação ou sociedade de economia mista; $\mathrm{V}$ - a associação que, concomitantemente a) esteja constituída há pelo menos 1 (um) ano nos termos da lei civil; b) inclua, entre suas finalidades institucionais, a proteção ao patrimônio público e social, ao meio ambiente, ao consumidor, à ordem econômica, 
ação penal pública cabe somente ao Ministério Público, não sendo possível reabrir as investigações arquivadas senão por existência de novas provas ${ }^{189}$.

Poder-se-ia objetar que, considerando que a última palavra caberia à própria instituição, seria desnecessária a participação do juiz. Contudo, o sistema de freios e contrapesos costuma valorizar a participação externa ao órgão responsável à decisão, que poderá fornecer uma visão diferente daquela que foi tida institucionalmente, aumentando o debate sobre a questão. Em uma comparação próxima, mesmo que uma lei seja aprovada no Congresso por quórum superior ao necessário para derrubar o veto (art. 66, $\S^{4^{190}}{ }^{19}$, ainda assim poderá o presidente opô-lo. Tal ato não teria sentido se não se pensasse na possibilidade do diálogo institucional, vindo alguns congressistas a reconsiderar seus votos. Do contrário, não haveria sentido em permitir a participação do Ministério Público em diversos procedimentos nos quais a ele cabe opinar, mas apenas aos órgãos julgadores decidir.

Desconsiderando esta situação, há orientação de órgãos de controle do Ministério Público Federal que sugerem aos membros da instituição a remessa direta do pedido de arquivamento a estes órgãos ${ }^{191}$. Esta orientação, sendo contrária ao disposto na legislação, além de não ter levado em consideração a possibilidade de outro Poder na formação da decisão a ser tomada, ainda implica em mais uma situação - a ser abordada posteriormente - pela qual é relevante reconhecer que o Ministério Público é um Poder: o órgão deve exercer autocontenção para não usurpar funções alheias.

Isto não significa que não se possa extinguir a participação do Judiciário nesta questão. O sistema de freios e contrapesos, desde que mantenha o equilíbrio, pode sempre ser alterado. Apenas se destaca que a situação hoje vigente é uma das possibilidades políticas, não estando fora dos limites constitucionais.

\subsubsection{Discordância do órgão julgador quando o Ministério Público postula a absolvição, "mutatio libelli" e "emendatio libelli"}

à livre concorrência, aos direitos de grupos raciais, étnicos ou religiosos ou ao patrimônio artístico, estético, histórico, turístico e paisagístico".

189 OLIVEIRA, Eugênio Pacelli de. Curso de Processo Penal. 14. ed. Rio de Janeiro: Lumen Juris, 2011, p. 62.

190 Art. 66. A Casa na qual tenha sido concluída a votação enviará o projeto de lei ao Presidente da República, que, aquiescendo, o sancionará (...) § $4^{\circ}$ O 0 veto será apreciado em sessão conjunta, dentro de trinta dias a contar de seu recebimento, só podendo ser rejeitado pelo voto da maioria absoluta dos Deputados e Senadores.

191 MINISTÉRIO PÚBLICO FEDERAL. Orientação Conjunta n. 01/2015. Disponível em: <http://s.conjur.com.br/dl/orientacao-conjunta012015.pdf>. Acesso em 14 mai. 2015.

Revista Publicum

Rio de Janeiro, v.2, n. 2, 2016, p. 120-168

http://www.e-publicacoes.uerj.br/index.php/publicum

DOI: 10.12957/publicum.2016.22787 
Há quem sustente que, se após a instrução o Ministério Público entender pela absolvição, o juiz estará vinculado a esta manifestação, não podendo condenar o réu ${ }^{192}$. Deve-se notar, contudo, o mesmo raciocínio já desenvolvido, de que sempre é possível estabelecer intervenções entre diferentes ramos do Estado. Neste ponto há ainda uma situação mais crítica para o sistema: se a tese alternativa ao que está disposto no CPP seria a de que o controle do arquivamento poderia ser transferido para um conselho superior colegiado ou para o chefe da instituição, neste caso não haveria previsão de remessa para estes órgãos.

Assim, caso se pretenda alterar a legislação para retirar do juiz a possibilidade de discordar do Ministério Público e emitir juízo condenatório, deve-se ao menos prever algum instituto para contrabalancear este poder. Por exemplo, tendo o órgão acusador entendido pela absolvição, faria uma comunicação ao juiz e remeteria os autos à instância de revisão do Ministério Público, que poderia insistir na absolvição ou postular pela condenação. Do contrário, ter-se-ia a situação anômala de o órgão do Ministério Público não poder, sem análise superior, arquivar inquérito civil (ao qual existe possibilidade de tutela por outros entes) ou peças investigativas criminais (ato que só faz coisa julgada formal ${ }^{193}$ ), mas ter o poder de determinar a coisa julgada material no âmbito criminal, sem qualquer possibilidade de contestação.

Embora não se vá aprofundar os temas, raciocínio semelhante pode ser aplicado em relação aos institutos da "mutatio libelli" (art. 384, CPP ${ }^{194}$ ) e "emendatio libelli" (art. $\left.383, \mathrm{CPP}^{195}\right)$. Ou seja, caso se pretenda diminuir a participação do juiz, aumentando sua vinculação à peça acusatória, deve-se pensar em um mecanismo para contrabalancear o poder de um órgão acusador singular.

O que se quer demonstrar de forma exemplificada é que, conforme já referido à exaustão, a ideia de que um ramo do governo não pode de nenhum jeito "interferir" nas funções do outro é uma concepção ultrapassada da teoria dos freios e contrapesos, tendo em vista que, concebida desta forma, não se poderia exercer contrabalanceamento adequado ${ }^{196}$. Há uma dimensão "positiva" da doutrina, consubstanciada no fato de que "a cada ramo foi dado o poder para exercer algum grau de controle direto sobre os outros,

192 MARTELETO FILHO, op. cit., p. 209-210.

193 OLIVEIRA, op. cit., p. 62.

194 Art. 384. Encerrada a instrução probatória, se entender cabível nova definição jurídica do fato, em consequência de prova existente nos autos de elemento ou circunstância da infração penal não contida na acusação, o Ministério Público deverá aditar a denúncia ou queixa, no prazo de 5 (cinco) dias, se em virtude desta houver sido instaurado o processo em crime de ação pública, reduzindo-se a termo o aditamento, quando feito oralmente.

195 Art. 383. O juiz, sem modificar a descrição do fato contida na denúncia ou queixa, poderá atribuir-lhe definição jurídica diversa, ainda que, em consequência, tenha de aplicar pena mais grave.

196 VILE, op. cit., p. 19. 
autorizando-o a exercer uma parte, embora apenas uma parte limitada, no exercício das funções dos demais" 197 .

O sistema de freios e contrapesos não é uma atividade acabada. Existem diversos diferentes pelo mundo, e deve-se sempre estar atento à possibilidade de desenvolvimento de novos mecanismos para realizar o balanço dos poderes ${ }^{198}$. A mera participação do Judiciário em algumas atividades da acusação no processo penal não implica a necessária violação do sistema acusatório, assim como a possibilidade de o Judiciário declarar a inconstitucionalidade de leis não elimina o princípio democrático.

Há quem postule um modelo de sistema acusatório extremo, como se isso fosse um valor por si, prescindindo da análise de que os mecanismos do Direito Processual Penal também tutelam outros princípios. Aliás, se fosse adotado a rigor o modelo acusatório que foi desenvolvido e consolidado ao longo de séculos na Inglaterra ${ }^{199}$, nem mesmo haveria um Ministério Público ${ }^{200}$. Conforme assentava René David, “A autoridade que vai tomar a iniciativa da ação penal é hoje, na Inglaterra, em geral, a polícia”, que o faz não como agente do Estado, mas na qualidade de bom cidadão ${ }^{201}$. Assim, o processo penal seria tal qual um processo civil, "é um processo entre particulares; não é uma luta desigual entre um acusador público, vestindo uma toga de magistrado, sentando-se no mesmo estrado do juiz, tendo relações de amizade com este, e um pobre coitado sobre o qual pesam, desde a origem do processo, as suspeitas" ${ }^{202}$. O sistema secular só foi alterado em 1985, passando a existir um órgão de acusação que auxilia a Polícia na persecução criminal, a qual ainda mantém a iniciativa da ação penal, em um sistema que compartilha funções ${ }^{203}$.

O que se pretende afirmar é a impossibilidade de se recorrer a um ideal de sistema acusatório que nem mais existe, como forma de afastar qualquer elemento que supostamente iria de encontro a este modelo cujo rigor já foi abandonado no próprio país onde ele existia. Nada impede a compatibilização da necessidade de distanciamento do juiz com a possibilidade de efetuar o contrabalanceamento das funções estatais.

197 VILE, op. cit., p. 19-20.

198 GROHMANN, Luís Gustavo Mello. A separação de poderes em países presidencialistas: a América Latina em perspectiva comparada. Revista de Sociologia e Política, n. 17, 2001, p. 88.

199 FERRAJOLI, Luigi. Direito e razão: teoria do garantismo penal. 3. ed. Ana Paula Zomer Siza et alli (trad.). São Paulo: Revista dos Tribunais, 2002, p. 453.

200 "Não há, na Inglaterra, Ministério Público" (DAVID, op. cit., p. 50). A primeira edição da obra, na língua francesa, é de 1967.

201 Ibidem. A primeira edição da obra, na língua francesa, é de 1967.

202 Ibidem, p. 50.

203 SANGUINÉ, Odone; SANGUINÉ, Paloma de Maman. A investigação criminal pelo Ministério Público no direito comparado e o retrocesso do Projeto de Emenda Constitucional (PEC) n. 37. Tribuna Virtual, n. 02, 2013, p. 14-15.

Revista Publicum

Rio de Janeiro, v.2, n. 2, 2016, p. 120-168

http://www.e-publicacoes.uerj.br/index.php/publicum

DOI: $10.12957 /$ publicum.2016.22787 


\subsection{A necessidade de não usurpação de funções pelo Ministério Público e} a investigação criminal

O reconhecimento do status de "Poder" ao Ministério Público também aumenta atenção ao fato de que a instituição deve promover sua autocontenção, atuando dentro do desenho constitucional estabelecido. Neste tópico, de forma semelhante ao anterior, não se discorrerá sobre situações exaustivas, mas apenas será demonstrada uma que corrobora com a ideia de que o Ministério Público deve respeitar o arranjo constitucional, não podendo usurpar funções de outros ramos governamentais.

Há muitas décadas existe a vontade de setores do Ministério Público de titularizar a presidência das investigações criminais ${ }^{204}$. Na década de 1970, Hélio Pereira Bicudo, à época Procurador de Justiça, sustentava que tal situação refletiria melhor a pretensão punitiva do Estado, e que, do contrário, a ação penal transforma-se em "veículo das imperfeições policiais"; assim, a solução estaria "em entregar a colheita da prova e sua prévia aferição ao Ministério Público"205. Houve Promotor que, em 1969, pleiteou ser confiada ao Parquet "a direção da Polícia Judiciária"206.

O pleito, embora não atendido, manteve-se nas décadas seguintes. No período anterior à Assembleia Constituinte, os presidentes de associações do Ministério Público, bem como os Procuradores-Gerais de Justiça de todo o Brasil elaboraram a "Carta de Curitiba", pela qual se buscava conferir ao Ministério Público "a supervisão dos procedimentos investigatórios, sua requisição e a possibilidade de avocá-los" ${ }^{207}$. No início da Constituinte, no debate nas subcomissões temáticas, a Confederação Nacional do Ministério Público postulou o poder da instituição para conduzir as investigações, havendo não mais o "inquérito policial”, mas o "inquérito preliminar" ${ }^{208}$, pleiteando ainda o controle sobre a polícia técnica ${ }^{209}$.

Em contraposição, a Associação dos Delegados de Polícia ponderou que o cargo de Delegado passava a ser carreira jurídica, havendo capacidade para o desenvolvimento da atividade investigatória, além do fato de que a condução pelo Ministério Público

204 MACHADO, Arnaldo de Carvalho et alli. A atuação do Ministério Público no inquérito policial. Justitia, n. 60, 1999, p. 603. O artigo originalmente foi publicado em 1974, por um grupo de estudos de membros da instituição.

${ }^{205}$ BICUDO, Hélio Pereira. A investigação criminal e o Ministério Público. Justitia, v. 70, 197?, p. 13.

206 INACARATO, op. cit., p. 515. A primeira publicação do artigo é de 1969.

207 SABELLA, Walter Paulo. Atividade policial: controle externo pelo Ministério Público. Justitia, n. 60,1999 , p. $1063-1064$.

208 ASSEMBLÉIA NACIONAL CONSTITUINTE. Atas da Subcomissão do Poder Judiciário e do Ministério Público. Brasília, 1987, p. 19-20.

209 Ibidem, p. 26. 
provocaria um desequilíbrio entre as partes $^{210}$. Em relação à possibilidade de o Promotor avocar o inquérito, afirmou-se a existência de duas atividades distintas: a de investigar e a de acusar, pelo que tal possibilidade somente deveria ser afeita aos órgãos corregedores da própria Polícia Judiciária211.

Já na Comissão de Sistematização, foi proposta por entidades da Polícia Militar a Emenda Popular n. 102, subscrita por quase quarenta mil eleitores, a qual buscava extinguir o inquérito policial, instaurando o juizado de instrução, com condução das investigações pelo Ministério Público ${ }^{212}$, proposta abraçada pelo Constituinte José Freire, que entendeu que “(..) não se deve e nem se pode admitir é a continuidade dessa figura denominada Delegado de Polícia (...)"213.

Diversas outras emendas foram propostas neste sentido durante a Constituinte, mas não vingaram ${ }^{214}$. Assim, a tese de investigação pelo Ministério Público foi especificamente rejeitada durante a Constituinte, tendo sido mantida apenas a possibilidade de requisição, adicionada do controle externo ${ }^{215}$. No entanto, sob a égide da nova Constituição, a postulação continuou a ser feita, vindo o Ministério Público do Paraná a editar a Resolução n. 97/1994, que estabeleceu diversas possibilidades de investigação direta pelos membros da instituição. No ano seguinte, surgiu em São Paulo o Grupo de Atuação Especial de Repressão ao Crime Organizado, com possibilidades semelhantes, iniciativa que se espalhou por todo o país.

Enquanto a atuação investigativa direta pelo próprio Ministério Público ainda não era tão impactante, o STF mantinha diversos julgados no sentido de ser algo inconstitucional $^{216}$. Em 2006, o Conselho Nacional do Ministério Público editou um esbulho normativo ${ }^{217}$, a resolução n. 13/2006, que sob o pretexto de "regulamentar"

210 Ibidem, p. 60-62.

211 Ibidem, p. 60-61.

212 ASSEMBLÉIA NACIONAL CONSTITUINTE. Atas da Comissão de Sistematização. Brasília, 1987, p. 416-418.

213 Ibidem, p. 419.

214 “O Constituinte rejeito as Emendas 945, 424, 1.025, 2.905, 20.524, 24.266 e 30.513, que, de um modo geral, davam ao Ministério Público a supervisão, avocação e o acompanhamento da investigação criminal” (STF. Segunda Turma. RHC 81326/DF. Rel. Min. Nelson Jobim. Julg. 06.05.2003. DJ 01.08.2003., p. 12 do acórdão).

215 SABELLA, Walter Paulo. Atividade policial: controle externo pelo Ministério Público. Justitia, n. 60, 1999, p. 1063-1064.

216 STF. Segunda Turma. RE 205473/AL. Rel Min. Carlos Velloso. Julg. 15.12.1998, DJ 13.03.1998; STF. Segunda Turma. RE 233072/RJ. Rel. p/ acórdão: Min. Nelson Jobim. Julg. 18.05.1999. DJ 03.05.2002. STF. Segunda Turma. RHC 81326/DF. Rel. Min. Nelson Jobim. Julg. 06.05.2003. DJ 01.08.2003.

217 Além de contrária ao direito material vigente à época, o ministro Marco Aurélio apontou haver violação à competência privativa da União para legislar sobre processo penal (STF. Tribunal Pleno. RE 593.727/MG. Rel. p/ acórdão Min. Gilmar Mendes. Julg. 14.05.2015. DJe 08.09.2015, p. 228 do acórdão). 
dispositivos legais, conferiu a aparência de legalidade ao antigo pleito do Ministério Público, estabelecendo a possibilidade de instauração de "procedimento investigatório criminal", ou seja, um "inquérito ministerial”.

O esbulho normativo resta claro não só pela análise da Constituinte, que rechaçou veemente esta possibilidade, além da jurisprudência do STF, como pelo fato de que os dispositivos legais que a Resolução afirma regular, quais sejam, o art. 8o da Lei Complementar 75/93 218 e o art. 26 da Lei n.o 8.625/93 219 , estabelecem que o Ministério Público pode requisitar a instauração de inquérito policial, requisitar diligências e acompanhá-las, não trazendo em nenhum momento a possibilidade de "instauração de procedimento investigatório criminal" ou a realização de diligências em investigações criminais. A impropriedade da resolução fica ainda mais patente quando se percebe que em relação ao inquérito civil a lei trouxe a previsão expressa de instauração bem como da promoção de diligências investigatórias.

Assim, o esbulho da função investigativa criminal direta, que o Constituinte expressamente rechaçou, foi normatizado pelo órgão que deveria exercer o controle sobre o Ministério Público. Considerando-se a expansão desta atividade pela instituição, principalmente voltada para o combate ao crime organizado, a situação foi tornando-se um fato consumado, difícil de ser revertido por razões mais pragmáticas do que propriamente jurídicas: seriam anuladas milhares de investigações, e em consequência os processos criminais, possibilitando a impunidade de diversos crimes gravíssimos.

Esta situação seria regulamentada pela PEC 37/2010, mantendo simetria com a concepção original do Constituinte e estabelecendo as hipóteses às quais não caberia a

2180 art. 8o estabelece prerrogativas para os membros do MPU "nos procedimentos de sua competência", sendo que o art. 7ํㅡㄹ estabelece que cabe aos seus membros: "I - instaurar inquérito civil e outros procedimentos administrativos correlatos; II - requisitar diligências investigatórias e a instauração de inquérito policial e de inquérito policial militar, podendo acompanhá-los e apresentar provas; III - requisitar à autoridade competente a instauração de procedimentos administrativos, ressalvados os de natureza disciplinar, podendo acompanhálos e produzir provas".

219 Art. 26. No exercício de suas funções, o Ministério Público poderá: I - instaurar inquéritos civis e outras medidas e procedimentos administrativos pertinentes e, para instruí-los: a) expedir notificações para colher depoimento ou esclarecimentos e, em caso de não comparecimento injustificado, requisitar condução coercitiva, inclusive pela Polícia Civil ou Militar, ressalvadas as prerrogativas previstas em lei; b) requisitar informações, exames periciais e documentos de autoridades federais, estaduais e municipais, bem como dos órgãos e entidades da administração direta, indireta ou fundacional, de qualquer dos Poderes da União, dos Estados, do Distrito Federal e dos Municípios; c) promover inspeções e diligências investigatórias junto às autoridades, órgãos e entidades a que se refere a alínea anterior; II requisitar informações e documentos a entidades privadas, para instruir procedimentos ou processo em que oficie; III - requisitar à autoridade competente a instauração de sindicância ou procedimento administrativo cabível; IV - requisitar diligências investigatórias e a instauração de inquérito policial e de inquérito policial militar, observado o disposto no art. 129, inciso VIII, da Constituição Federal, podendo acompanhá-los; V - praticar atos administrativos executórios, de caráter preparatório; 
investigação pela Polícia Judiciária. Tendo sido aprovada na Comissão Especial da Câmara no final de 2012, recebeu das entidades de classe do Ministério Público a alcunha de "PEC da Impunidade" - embora houvesse ressalva expressa pela validade das investigações realizadas pela instituição até a data de publicação -, o que acabou implicando em sua rejeição em $2013^{220}$.

Com efeito, a PEC 37/2010 estabeleceria uma função privativa que, na prática, seria impossível de observar. Isto porque diversas outras instituições investigam administrativamente condutas de também seriam passíveis de punição criminal ${ }^{221}$. Contudo, deve-se observar, estes órgãos investigam delitos apenas subsidiariamente - sua atuação principal está voltada para o âmbito administrativo - e dentro de sua especialidade, não sendo cabível, por exemplo, à Receita Federal investigar homicídio.

Assim, também, o Ministério Público deve ter a possibilidade de realizar investigações apenas quando necessário ${ }^{222}$, uma atuação subsidiária, excepcional, na esteira do que vinha entendendo o STF: quando há suspeita de envolvimento das autoridades policiais da delegacia local nos fatos delituosos ${ }^{223}$; em casos nos quais questões políticas poderiam interferir na investigação, notadamente se o Delegado de Polícia da localidade tem atuação partidária ${ }^{224}$; para complementar os elementos de convicção já colhidos no inquérito policial ${ }^{225}$; em hipóteses de cometimento de tortura por policiais ${ }^{226}$; caso haja intencional omissão da polícia ${ }^{227}$. Pode-se cogitar de outras possibilidades: se os fatos criminosos investigados apareceram em apurações cíveis do próprio órgão ministerial; se o órgão policial a quem caberia o procedimento estiver com sobrecarga de trabalho, e o mesmo não se verificar quanto ao membro do Parquet, dentre outras.

220 ZANOTTI, Bruno Taufner; SANTOS, Cleopas Isaías. Delegado de Polícia em ação: teoria e prática. Salvador: Juspodivm, 2013, p. 44.

221 CALABRICH, Bruno Freire de Carvalho. Investigação Criminal pelo Ministério Público: fundamentos e limites constitucionais. Dissertação (mestrado em Direito). Faculdade de Direito de Vitória, Vitória, 2006, p. 86-88.

222 FERNANDES, Vivian Baptistella. A comparação entre a atuação do Ministério Público na justiça criminal brasileira e a do Gabinete do Procurador no Tribunal Penal Internacional. Revista Jurídica da Escola Superior do Ministério Público de São Paulo, v. 5, 2014, p. 294.

223 STF. Segunda Turma. HC 96986/MG. Rel. Min. Gilmar Mendes. Julg. 15.05.2012. DJe 14.09.2012.

224 De maneira próxima: STF. Segunda Turma. HC 91613/MG. Rel. Min. Gilmar Mendes. Julg. 15.05.2012. DJe 17.09.2012. No entanto, a fundamentação considerou que o mero fato de haver envolvimento de vereadores justificava esta atuação, entendimento do qual se discorda.

225 STF. Tribunal Pleno. HC 84548/SP. Rel p/ acórdão Min. Gilmar Mendes. Julg. 04.03.2015. DJe 10.04.2015.

226 STF. Segunda Turma. HC 93930/RJ. Rel. Min. Gilmar Mendes. Julg. 07.12.2010. DJe 03.02.2011.

227 Como sugerido pelo relator do acórdão, embora não fosse a questão do recurso: STF. Tribunal Pleno. RE 593.727/MG. Rel. p/ acórdão Min. Gilmar Mendes. Julg. 14.05.2015. DJe 08.09.2015, p. 100 do acórdão. 
Ao julgar esta questão em 2015, submetida ao regramento da repercussão geral, o relator para o acórdão, Ministro Gilmar Mendes, sustentou que “Daí, o entendimento de que as investigações realizadas no seio daquela instituição devam ser, necessariamente, subsidiárias, ocorrendo, apenas, quando não for possível, ou recomendável, se efetivem pela própria polícia (...) só se justifica constitucionalmente o exercício da função investigativa, por quem não possui essa função constitucional precípua, a partir do reconhecimento do aspecto subsidiário dessa atividade ${ }^{228 " . ~ E m b o r a ~ e s t a ~ s i t u a c ̧ a ̃ o ~ n a ̃ o ~}$ tenha ficado expressa na tese, tendo em vista que os ministros não chegaram a um consenso acerca das hipóteses excepcionais, seguramente compôs a ratio decidendi do acórdão, tendo sido a subsidiariedade da investigação criminal pelo Ministério Público lembrada por outros ministros 229 .

Gilmar Mendes acrescentou que o tema precisa ser regulamentado por lei ${ }^{230}$ - algo que se mostra premente, ainda que não seja feito de forma taxativa - e reverberou ainda o posicionamento do Ministro Luís Roberto Barroso: "não é desimportante lembrar que a Polícia se sujeita ao controle do Ministério Público. Mas se o Ministério Público desempenhar, de maneira ampla e difusa, o papel da Polícia, quem irá fiscalizá-lo?"231.

Assim, deve haver um ônus de fundamentação para o ato que instaure investigação criminal pelo Ministério Público, explicitando o motivo pelo qual não se solicita a investigação à autoridade policial, sob possibilidade de impetração de habeas corpus para trancar a investigação, bem como responsabilização administrativa do órgão ministerial. A subsidiariedade das investigações criminais pelo Parquet é a única interpretação que pode, ainda que com o reconhecimento de ter havido mutação constitucional, coadunar-se com as decisões constituintes ${ }^{232}$. Do contrário, vindo o

228 STF. Tribunal Pleno. RE 593.727/MG. Rel. p/ acórdão Min. Gilmar Mendes. Julg. 14.05.2015. DJe 08.09.2015, p. 90 do acórdão.

${ }^{229}$ Assim, por exemplo, Min. Luiz Fux: STF. Tribunal Pleno. RE 593.727/MG. Rel. p/ acórdão Min. Gilmar Mendes. Julg. 14.05.2015. DJe 08.09.2015, p. 210 do acórdão. Três ministros propuseram uma subsidiariedade ainda maior, mais que não foi aceita, conforme voto de Cezar Peluso, de que a investigação pelo Parquet "(...) que tenha por objeto fato ou fatos teoricamente criminosos, praticados por membros ou servidores da própria instituição (a), ou praticados por autoridades ou agentes policiais (b), ou, ainda, praticados por outrem, se, a respeito, a autoridade policial, cientificada, não haja instaurado inquérito policial (a) (ibidem, p. 50 do acórdão).

230 STF. Tribunal Pleno. RE 593.727/MG. Rel. p/ acórdão Min. Gilmar Mendes. Julg. 14.05.2015. DJe 08.09.2015, p. 93 do acórdão.

231 STF. Tribunal Pleno. RE 593.727/MG. Rel. p/ acórdão Min. Gilmar Mendes. Julg. 14.05.2015. DJe 08.09.2015, p. 90 do acórdão.

232 Poder-se-ia questionar quanto à suposta falta de simetria neste trabalho em relação à possibilidade de reconhecer o Ministério Público como "quarto poder" e à possibilidade de investigação. Deve-se notar, contudo, que a definição acerca de ser o Ministério Público um "poder" não foi objeto de deliberação na Constituinte, ou seja, não foi explicitamente rechaçada. Ao contrário, se colocou diversos dispositivos que seguiam neste sentido. A possibilidade de 
Ministério Público - que é um poder com total independência e ampla possibilidade de controle da investigação policial - a adensar sua participação na fase de investigação, haverá a diminuição do contrabalanceamento existente entre os atores governamentais, situação com potencial de descambar para o desequilíbrio ${ }^{233}$.

Em relação às consequências jurídicas da investigação indevida, entende-se que os resultados de tal atuação, desde que tenha respeitado os direitos constitucionais e legais, não devem ser anulados. Se até mesmo particulares podem investigar ${ }^{234}$, notadamente os jornalistas ou envolvidos, e os elementos colhidos serem utilizados posteriormente, não há razão para que não o seja em relação a um ente estatal. Assim, somente seria cabível a responsabilização administrativa do servidor que se desvia injustificadamente de suas funções precípuas.

Não se está dizendo, com isso, que não é possível o atendimento do antigo pleito ministerial de lhe atribuir a primazia da investigação criminal. Isto, contudo, deve ser feito de forma democrática, com participação da população e por meio de procedimento no Congresso. Este é o modo mais seguro de se evitar desvios inconstitucionais, afinal, nenhum dos "poderes" é imune à tentação de abusar do poder e se sobrepor aos demais $^{235}$. E tal reconhecimento posterior não alterará o fato histórico de que o início da possibilidade investigativa do órgão se deu de forma escusa, "a fórceps", ignorando completamente as decisões do Constituinte e do STF à época, algo que não deve ser esquecido, para que não se permita repetir.

Ademais, visualiza-se um óbice ao alcance desta alteração em relação à Polícia Federal, tendo em vista que a Constituição a colocou como órgão permanente (art. 144, $\left.\S 1^{\mathbf{o}^{236}}\right)$. Sendo a apuração de infrações penais a sua principal atuação - à semelhança do que é a acusação para o Ministério Público -, a alienação desta função implicaria em vazio institucional, uma diminuição incompatível com o caráter de um órgão permanente.

Em sentido próximo manifestavam-se membros do Ministério Público no período anterior à Constituição de 1988: em que pesasse a falta de norma constitucional - ou até de norma legal expressa acerca da exclusividade -, o poder de acusar era algo

investigação do órgão, no entanto, foi diversas vezes discutida e rejeitada, pelo que a decisão do Constituinte só deveria poder ser alterada por Emenda Constitucional.

233 Esta conclusão pode ser obtida com base no quadro-síntese de Luís Gustavo Mello Grohmann, ao demonstrar que se um poder possui alta independência e alta possibilidade de checar a atividade do outro, é necessário que também o outro possua estas duas características, sob pena de desequilíbrio (op. cit., p. 87).

234 ZANOTTI; SANTOS, op. cit., p. 52.

235 VILE, op. cit., p. 408.

236 Art. 144 (...) § 1ํA A polícia federal, instituída por lei como órgão permanente, organizado e mantido pela União e estruturado em carreira, destina-se a: (...) 
“intimamente ligado à vida e à história da Instituição”, e por isso deveria ser observado, sob pena de "esvaziamento institucional" 237 . Seria, de forma semelhante, como retirar da Defensoria Pública a função de representação judicial individual, ainda que mantendo a instituição com outras funções.

$E$, talvez, justamente com base na ideia de que o poder de investigar faz parte do sistema de balanceamento entre poderes ${ }^{238}$ é que houve esta opção do Constituinte de dotar a Polícia Federal com a característica da permanência, ou seja, seria uma forma de contrabalancear Executivo com Ministério Público. Assim, não apenas se decidiu à época que não caberia ao Parquet as investigações, como se estabeleceu que elas seriam mantidas em outro ramo governamental, ao menos na esfera federal ${ }^{239}$.

Ao final deste tópico, entende-se fundamentada a posição inicial: o Ministério Público, enquanto um Poder constitucional, deve observar o arranjo institucional estabelecido, não podendo usurpar funções que democraticamente lhe foram negadas, utilizando de sua proeminência política que Ihe foi outorgada de forma inédita pela Constituição Federal de 1988.

\section{Conclusões}

Com base no que foi exposto, pode-se concluir que a chamada teoria da separação dos poderes, em verdade, corresponde à teoria da repartição das funções estatais, e que, tomada em um sentido rigoroso, jamais permitiria a estabilidade de um governo. Primeiro porque nenhum ramo estatal exerce verdadeiramente apenas uma função. Segundo porque - e de forma mais importante de salientar - o compartilhamento do poder deve ser acrescido de um mecanismo de freios e contrapesos que não permita a hipertrofia de nenhum dos Poderes, podendo sempre ser atualizado e reconfigurado, desde que mantenha o equilíbrio.

Embora haja uma dificuldade inicial textual da Constituição Federal, o reconhecimento é possível a partir da análise substancial das possibilidades que o

237 KURTZ, João Carlos. A Instituição do Ministério Público perante a Ação Penal Pública. Justitia, n. 60,1999 , p. 886-887. 0 artigo foi publicado pela primeira vez em 1982. Segundo o autor, como a Lei Orgânica da instituição à época (LC 40/81) afirmava apenas que era vedado o exercício das funções do Ministério Público a pessoas estranhas à carreira, houve a interpretação de que tal dispositivo apenas proibia a existência de promotor ad hoc, mas não que outros órgãos fossem incumbidos da atividade.

238 GROHMANN, op. cit., p. 88.

239 Pode-se formular também a hipótese de que a falta de previsão da permanência para a Polícia Civil e Polícia Militar foi calcada numa previsão de que, futuramente, poder-se-ia entender por bem a unificação das instituições, mas não que se poderia tirar a função investigativa deste âmbito. 
Constituinte concedeu ao Ministério Público, da falta de menção constitucional expressa a outros Poderes existentes, bem como que não houve qualquer tipo de afastamento expresso desta questão nos debates da Constituinte.

O reconhecimento do Ministério Público como um "Quarto Poder" não é uma questão de pouca importância, como se fosse apenas para conferir mais ou menos prestígio aos seus membros. Tal reconhecimento, embora desnecessário do ponto de vista estritamente lógico, é bastante relevante quando possibilita chamar atenção para dois fatos: o de que a instituição participa do sistema de freios e contrapesos, pelo que é possível que os outros Poderes interfiram em suas atividades precípuas, bem como que ela deve observar o desenho constitucional, não podendo turbar e esbulhar funções alheias de modo antidemocrático.

Deste modo, é possível que o Ministério Público atue na tomada de decisões dos outros Poderes, bem como que estes exerçam funções nas atividades ministeriais, sem que isso signifique um afastamento da relativa independência dos ramos governamentais. De igual modo, caso se entenda que o Ministério Público deve ter mais funções do que as que Ihe são atribuídas hoje, as alterações devem passar pelo necessário processo democrático, não podendo a instituição utilizar da sua proeminência constitucional para forçar as mudanças pretendidas.

\section{Referências}

ABREU, João Paulo Pirôpo de. A autonomia financeira do poder judiciário: limites traçados pelo princípio da independência e harmonia dos poderes. Dissertação (mestrado em Direito). Universidade Federal da Bahia, 2012.

ALBUQUERQUE, Afonso de. Um outro "Quarto Poder": imprensa e compromisso político no Brasil. Contracampo, n. 4, 2000, p. 23-57.

ALEXY, Robert. Teoria dos Direitos Fundamentais. 2. ed. Virgílio Afonso da Silva (trad.). São Paulo: Malheiros, 2011.

ARISTÓTELES. A política. Nestor Silveira Chaves (trad.). Rio de Janeiro: Nova Fronteira, 2011.

ASSEMBLÉIA NACIONAL CONSTITUINTE. Atas da Comissão de Sistematização. Brasília, 1987.

. Atas da Subcomissão do Poder Judiciário e do Ministério Público. Brasília, 1987. 
ASSOCIAÇÃO NACIONAL DOS PROCURADORES DA REPÚBLICA. Ministério Público é o quarto Poder, afirma Temer, 04 nov. 2009. Disponível em: <http://anpr.org.br/noticia/1832>. Acesso em 07 mai. 2016.

BARENBOIM, Peter. Biblical roots of separation of powers. Moscou: Letny Sad, 2005.

BARROSO, Luís Roberto. Curso de Direito Constitucional Contemporâneo: os conceitos fundamentais e a construção do novo modelo. 4. ed. São Paulo: Saraiva, 2013.

BELLAMY, Richard. The political form of the constitution: the separation of powers, rights and representative democracy. Political Studies, v. 44, n. 3, 1996, p. 436-456.

BICUDO, Hélio Pereira. A investigação criminal e o Ministério Público. Justitia, v. 70, 197?, p. 7-21.

BOLINGBROKE. Craftsman. Londres: R. Francklin, 1731, v. 7. Disponível em: <https://archive.org/stream/craftsman07danv\#page/n7/mode/2up>. Acesso em 24 abr. 2016.

BONAVIDES, Paulo. Ciência Política. 18. ed. São Paulo: Malheiros, 2011.

BOTELHO, João Carlos Amoroso. A democracia na Venezuela da era chavista. Aurora, v. 1, n. 2, 2008, p. 18-25.

BRITTO, Carlos Ayres. O regime constitucional do Tribunal de Contas. Revista do Tribunal de Contas do Estado do Rio de Janeiro, v. 2, n. 8, 2014, p. 9-20.

BROOKHISER, Richard. Founding father: rediscovering George Washington. Nova lorque: Free Press Paperbacks, 1997.

BURLE FILHO, José Emmanuel. O Ministério Público e sua posição Constitucional. Justitia, n. 60, 1999, p. 1057-1061.

CALABRESI, Steven G.; BERGHAUSEN, Mark E.; ALBERTSON, Skylar. The rise and fall of the separation of powers. Northwestern University Law Review, v. 106, n. 2, 2012, p. 527-549.

CALABRICH, Bruno Freire de Carvalho. Investigação Criminal pelo Ministério Público: fundamentos e limites constitucionais. Dissertação (mestrado em Direito). Faculdade de Direito de Vitória, Vitória, 2006.

CAMARGO, Margarida Maria Lacombe. Prefácio. In: RAMOS, Carlos Henrique. Mutação constitucional: constituição e identidade constitucional evolutiva. Curitiba: Juruá, 2013, p. 13-17.

CAMPOS, Carlos Alexandre de Azevedo. Explicando o avanço do ativismo judicial do Supremo Tribunal Federa. In: FELLET, André; NOVELINO, Marcelo (org.). Constitucionalismo e democracia. Salvador: Juspodivm, 2013?, p. 349-409.

CANOTILHO, J. J. Gomes. Teoria da Constituição e Direito Constitucional. 6. ed. rev. Coimbra: Almedina, 1993. 7. ed. Coimbra: Almedina, 2003. 
CAVALCANTE FILHO, João Trindade. Processo Legislativo Constitucional. Salvador: Juspodivm, 2012.

CLAUS, Laurence. Montesquieu's mistakes and the true meaning of separation. Oxford Journal of Legal Studies, v. 25, n. 3, 2005, p. 419-451.

CONTI, José Maurício. Poderes não são independentes sem autonomia financeira. Conjur, 27 ago. 2013. Disponível em: <http://www.conjur.com.br/2013-ago-27/contas-vistapoderes-nao-sao-independentes-autonomia-financeira>. Acesso em 03 jul. 2016.

CUNHA JR., Dirley. Curso de Direito Constitucional. 7. ed. Salvador: Juspodivm, 2013.

DAVID, René. O direito inglês. 2. ed. Eduardo Brandão (trad.). São Paulo: Martins Fontes, 2006.

DIDIER JR., Fredie. Curso de Direito Processual Civil: introdução ao direito processual civil, parte geral e processo de conhecimento. 17. ed. Salvador: Juspodivm, 2015, v. 1.

DUIGNAN, Brian. The executive branch of the federal government: purpose, process, and people. Nova lorque: Britannica Educational, 2010.

FARBER, Daniel A.; SHERRY, Suzanna. Judgment calls: principle and politics in constitutional law. Nova lorque: Oxford University Press, 2009.

FERNANDES, Vivian Baptistella. A comparação entre a atuação do Ministério Público na justiça criminal brasileira e a do Gabinete do Procurador no Tribunal Penal Internacional. Revista Jurídica da Escola Superior do Ministério Público de São Paulo, v. 5, 2014, p. 283308.

FERRAJOLI, Luigi. Direito e razão: teoria do garantismo penal. 3. ed. Ana Paula Zomer Siza et alli (trad.). São Paulo: Revista dos Tribunais, 2002.

GARCIA, Emerson. Ministério Público: organização, atribuições e regime jurídico. 5. ed. São Paulo: Saraiva, 2015.

GROHMANN, Luís Gustavo Mello. A separação de poderes em países presidencialistas: a América Latina em perspectiva comparada. Revista de Sociologia e Política, n. 17, 2001, p. 75-106.

GUMMERE, Richard M. The classical ancestry of the United States Constitution. American Quarterly, v. 14, n. 1, 1962, p. 3-18.

HAMILTON, Alexander; JAY, John; MADISON, James. The Federalist. Nova lorque: The Colonial Press, 1901.

HERNÁNDEZ, Janeth. Organización electoral y credibilidade: caso Venezuela (1989-2005). Cuestiones Políticas, v. 22, n. 37, 2006, p. 94-108.

HOBBES, Thomas. Leviathan: or the matter, forme \& power of a commonwealth, ecclesiasticall and civil. Cambridge: Cambridge University, 1904. 
INACARATO, Márcio Antônio. O Ministério Público na ordem jurídico constitucional. Justitia, n. 60, 1999, p. 470-515.

KELSEN, Hans. Teoria geral do direito e do estado. Luís Carlos Borges (trad.). 3. ed. São Paulo: Martins Fontes, 2000.

KEMP, Christopher. Madison, Montesquieu and the separation of powers. In: COULSON, Andrew (ed.). Scrutiny: theory and practice in local governance. Birmingham: University of Birmingham, 2010, p. 47-58.

KIMMINICH, Otto. A jurisdição constitucional e o princípio da divisão dos poderes. Anke Schlimm e Gilmar Ferreira Mendes (trad.). Revista de Informação Legislativa, Brasília, $\mathrm{n}$. 105,1990, p. 283-302.

KRAMNICK, Isaac. Bolingbroke and his circle: the politics of nostalgia in the Age of Walpole. Ithaca: Cornell University Press, 1992.

KURTZ, João Carlos. A Instituição do Ministério Público perante a Ação Penal Pública. Justitia, n. 60, 1999, p. 886-890.

LOCKE, John. Segundo tratado do governo civil: ensaio sobre a origem, os limites e os fins verdadeiros do governo civil. 3. ed. Magda Lopes; Marisa Lobo da Costa (trad.). Petrópolis: Vozes, 2001.

LOEWENSTEIN, Karl. The balance between legislative and executive power: a study in comparative constitutional law. University of Chicago Law Review, v. 5, n. 4, 1938, p. 566608.

LOPES, João. O Ministério Público e o quarto Poder. Revista Jus Navigandi, $\underline{\mathrm{n}}$. 3516, 15 fev. 2013. Disponível em: <https://jus.com.br/artigos/23730>. Acesso em: 06 mai. 2016.

LOPES JR. Aury. Sistemas de investigação preliminar no processo penal. Rio de Janeiro: Lumen Juris, 2001.

LYNCH, Christian Edward Cyril. O discurso político monarquiano e a recepção do conceito de poder moderador no Brasil (1822-1824). Revista Dados de Ciências Sociais, Rio de Janeiro, v. 48, n. 3, 2005, p. 611-654.

MACHADO, Arnaldo de Carvalho et alli. A atuação do Ministério Público no inquérito policial. Justitia, n. 60, 1999, p. 596-606.

MAGALHÃES, José Luiz Quadros de. A teoria da separação de poderes e a divisão das funções autônomas no Estado contemporâneo: o Tribunal de Contas como integrante de um poder autônomo de fiscalização. Revista do Tribunal de Contas do Estado de Minas Gerais, v. 71, n. 2, 2009, p. 92-101.

MARTELETO FILHO, Wagner. Sistema acusatório e garantismo: uma breve análise das violações do sistema acusatório no Código de Processo Penal. De jure, Belo Horizonte, n. 12, 2009, p. 193-217. 
MAZZILLI, Hugo Nigro. O Ministério Público e Constituinte. Justitia, n. 60, 1999, p. 989993.

. O Ministério Público no processo penal. Justitia, n. 60, 1999, p. 665-668.

MENDES, Gilmar Ferreira; BRANCO, Paulo Gustavo Gonet. Curso de direito constitucional. 9. ed. São Paulo: Saraiva, 2014.

MINISTÉRIO PÚBLICO FEDERAL. Orientação Conjunta n. 01/2015. Disponível em: <http://s.conjur.com.br/dl/orientacao-conjunta-012015.pdf>. Acesso em 14 mai. 2015.

MONTESQUIEU. Do espírito das leis. Gabriela de Andrada Dias Barbosa (trad.). Rio de Janeiro: Nova Fronteira, 2012, v. 1.

MORAES, Alexandre de. Limitações constitucionais às comissões parlamentares de inquérito. Revista de Informação Legislativa, n. 146, 2000, p. 281-289.

OLIVEIRA, Eugênio Pacelli de. Curso de Processo Penal. 14. ed. Rio de Janeiro: Lumen Juris, 2011.

OMMATI, Fides. Dos freios e contrapesos entre os poderes do estado. Revista de Informação Legislativa, Brasília, n. 55, 1977, p. 55-82.

PERELMAN, Chaïm; OLBRECHTS-TYTECA, Lucie. 2. ed. Maria Ermantina de Almeida Prado Galvão (trad.). São Paulo: Martins Fontes, 2005.

POSNER, Eric A. Balance-of-Powers arguments and the Structural Constitution. University of Chicago Institute for Law \& Economics Olin Research Paper, n. 622, 2012. Disponível em: <http://ssrn.com/abstract=2178725>. Acesso em 07 mai. 2016.

RAMOS, Carlos Henrique. Mutação constitucional: constituição e identidade constitucional evolutiva. Curitiba: Juruá, 2013.

REINO UNIDO DA GRÃ-BRETANHA E IRLANDA DO NORTE. Ministério da Justiça. Review of the executive royal prerogative powers: final report. Ministério da Justiça: Londres, 2009.

SABELLA, Walter Paulo. Atividade policial: controle externo pelo Ministério Público. Justitia, n. 60, 1999, p. 1062-1069.

SANGUINÉ, Odone; SANGUINÉ, Paloma de Maman. A investigação criminal pelo Ministério Público no direito comparado e o retrocesso do Projeto de Emenda Constitucional (PEC) n. 37. Tribuna Virtual, n. 02, 2013, p. 7-31.

SARLET, Ingo Wolfgang; MARINONI, Luiz Guilherme; MITIDIERO, Daniel. Curso de Direito Constitucional. 3. ed. rev. atual. ampl. São Paulo: Revista dos Tribunais, 2014.

SHACKLETON, Robert. Montesquieu, Bolingbroke, and the separation of powers. French Studies, v. 3, n. 1, 1949, p. 26. p. 25-38.

SILVA, Virgílio Afonso da. Interpretação Constitucional e Sincretismo Metodológico. In: SILVA, Virgílio Afonso da (org.). Interpretação Constitucional. São Paulo: Malheiros, 2007, p. $115-143$. 
SMITH, Goldwin. Special introduction. In: HAMILTON, Alexander; JAY, John; MADISON, James. The Federalist. Nova Iorque: The Colonial Press, 1901.

THOMÉ, Romeu. Manual de Direito Ambiental. 5. ed. Salvador: Juspodivm, 2015.

VILE, M. J. C. Constitutionalism and the separation of powers. 2. ed. Indianapolis: Liberty Fund, 1998.

ZANOTTI, Bruno Taufner; SANTOS, Cleopas Isaías. Delegado de Polícia em ação: teoria e prática. Salvador: Juspodivm, 2013.

Recebido em 15/05/2016

Aceito em 23/11/2016 